\title{
A EXPLOSÃO DOS CONDOMÍNIOS FECHADOS NA REGIÃO METROPOLITANA DA GRANDE VITÓRIA - ESPÍRITO SANTO - BRASIL
}

L'EXPLOSION DES «RESIDENCES SURVEILLÉES 》 (CONDOMINIUMS FERMÉS) DANS LA RÉGION MÉTROPOLITAINE DE VITÓRIA - ESPÍRITO SANTO BRÉSIL

THE EXPLOSION OF GATED COMMUNITIES IN THE METROPOLITAN AREA OF VITÓRIA - ESPÍRITO SANTO - BRAZIL

Cláudio Luiz Zanotelli Departamento e Mestrado em Geografia - Ufes clzanotelli@yahoo.com.br

Larissa Marques de Antônio Departamento de Geografia - Ufes larissamarquesantonio@gmail.com

Francismar Cunha Ferreira Departamento de Geografia - Ufes francismar.funha@gmail.com

Bruno da Silva Departamento de Geografia - Ufes br.geografia@gmail.com 


\title{
RESUMO
}

Estudo dos diferentes apectos (urbanos, ambientais e de vida cotidiana) dos construtos socioespaciais, que são os hábitats enclausurados, a partir da análise de sua proliferação em Serra: um Município da Região Metropolitana de Vitória - Espírito Santo, Brasil. Exposição inicial dum panorama geral acerca dos condomínios fechados implantados nesse município, partindo-se da análise de suas tipologias e das estratégias de expansão da mancha urbana, associadas a esses empreendimentos. Realização de três estudos de casos em que consistem três distintos tipos de condomínios existentes, cujas temporalidades e espacialidades são díspares e podem traduzir sinteticamente as problemáticas associadas a esse tipo de expansão do/no espaço urbano.

Palavras-chave: Autossegregação. Condomínios fechados. Região Metropolitana da Grande Vitória.

\section{RÉSUMÉ}

Analyse des différents aspects (urbains, environnementaux et la vie quotidienne) des « résidences surveillées » dans la région métropolitaine de Vitória, état de l'Espírito Santo au Brésil. Exposition d'un tableau de ces ensembles dans la municipalité de Serra (Région Métropolitaine de Vitória). L'établissement d'une typologie de ces habitats et l'étalement urbain qui leur est associé. Réalisation de trois études de cas de ces différents ensembles dans la municipalité de Serra, ceux-ci ont des temporalités et spatialités hétérogènes qui représentent les différentes sortes des problèmes liés à ce type d'habitat.

Mots-clés : Ségrégation. Résidences surveillées. Région Métropolitaine de Vitória, Brésil

\begin{abstract}
This article is about the urban, the environmental and the daily life of the socio-spatial constructs that are enclosed habitats, studied their proliferation in a municipality of metropolitan region of Vitória in Espírito Santo, Brazil. Initially, offer an overview about the Gateds communities in the Serra municipality, there analyzed the typology of these strategies and the expansion of urban broad which are associated with them. Then, we conducted three case studies on different types the Gateds communities of existing in Serra that have disparate temporalities and spatiality's and that could translate the problems associated with this type of expansion the urban space.
\end{abstract}

Keywords: Gateds communities. Metropolitan region of Vitória in Espírito Santo, Brazil. 


\section{INTRODUÇÃO}

$\mathrm{O}$ artigo se inscreve no quadro de nossas pesquisas sobre as violências, fragmentações e autossegregações no espaço urbano (ZANOTELLI et al., 2009; ZANOTELLI et. al., 2010; ZANOTELLI, 2011; ZANOTELLI; FERREIRA, 2011; ZANOTELLI; FERREIRA, 2012).

Os condomínios e/ou loteamentos fechados - ou exclusivos -, os "bairros cerrados", as "gateds communities" têm-se expandido em nível mundial ${ }^{1}$. No Brasil, a propagação desse hábitat ${ }^{2}$ deve ser vista em conformidade com a atual dinâmica urbana decorrente de discursos e práticas fundamentados na cultura da generalização do medo e da sensação de insegurança vivenciada nas cidades. Tais processos de autossegregação incrementados pelas classes dominantes e por parte das classes médias se estendem para alguns bairros de classes sociais dominadas e para os programas de habitação financiados pelo governo federal Minha casa, minha vida.

Esses processos poderiam associar-se àquilo que certos autores chamam de militarização do espaço urbano. Para Stephen Graham (2012 [2010]), a tecnologia e os procedimentos militares invadem a vida cotidiana e as cidades. Os procedimentos coloniais de controle dos países do Norte e das multinacionais nos territórios dos Estados que dispõem de matériasprimas, situados ao Sul, são repercutidos tanto nas cidades dos países ditos desenvolvidos como naquelas dos países ditos em desenvolvimento ou "emergentes". Assim como as cidades ocupadas, de Bagdad ou Cabul, são vigiadas e têm bairros autossegregados do conjunto do tecido urbano como forma de securização, há setores de cidades noutros lugares que se põem sob um controle que usa tecnologia de origem militar. Tal tecnologia, que se utiliza de câmeras potentes, para vigiar ruas, prédios e conjuntos habitacionais, que usa os Globals Positionings Systems (GPSs), presentes em aparelhos celulares, para identificar os sujeitos onde estejam, também define padrões de biótipos dos que circulam nesses espaços reservados, montam bases de dados sobre as pessoas que ali residem e selecionam antecipada e aleatóriamente aqueles que podem representar um suposto perigo para a “comunidade". Constitui-se, dessa forma, um arquipélago urbano, um urbanismo securitário de inspiração militar, que promove uma economia do vigiar. Desse modo, nos diz Graham (Op. cit, p.23: tradução nossa):

(...) as ideias securitárias contaminam quase todos os aspectos das políticas públicas e da vida social tão bem que essas novas indústrias da segurança

\footnotetext{
${ }^{1}$ A propósito da fragmentação urbana e da produção dos condomínios e loteamentos fechados em nível mundial, pode-se ler o balanço realizado por Françoise Navez-Bouchanine, 2002.

${ }^{2}$ De acordo com dados de Moura (2003), no ano de 2002, 2,5\% da classe média brasileira decidiu pelos condomínios fechados como modo de habitação. Nos últimos 5 anos, os números desse tipo de habitação dobraram.
}

Geo UERJ - Ano 14, no. 23, v. 2, $2^{\circ}$ semestre de 2012 p. 619-655

ISSN: 1415-7543 E-ISSN: 1981-9021

http://www.e-publicacoes.uerj.br/index.php/geouerj 
trabalham juntas, para levantar os desafios altamente lucrativos, colocados pela vigília permanente das atividades cotidianas, dos espaços e dos comportamentos urbanos, assim como das redes que religam as aglomerações entre si. Em pleno naufrágio econômico mundial, os mercados de serviços e de tecnologias de segurança conhecem uma expansão sem precedentes.

No Brasil, as seguranças privadas têm hoje efetivos maiores que as polícias civis e militares em diversos Estados brasileiros. Os investimentos em câmeras para vigiar ruas e pontos públicos, os controles por meio de fichas, fotografias, impressões digitais nas entradas de imóveis e conjuntos residenciais fechados e em sede de empresas e prédios comerciais se tornaram algo comum, inclusive nas Universidades ${ }^{3}$. As promessas dos gestores e políticos é de que a criminalidade e a delinquência se reduzirão. Em nome desses controles se inculcam cada vez mais nos sujeitos o sentimento de serem vigiados e a injunção subjetiva de vigiar os outros, sem necessariamente serem obrigados a fazê-lo de maneira deliberada. Difundemse os sentimentos de desconfiança do Outro e se assume, inconscientemente ou não, o papel de polícia em relação ao conjunto da sociedade. É como se estivéssemos numa cruzada permanente ou numa "guerra permanente", para buscar os" elementos perigosos" no seio da sociedade. Assim, as sociedades contemporâneas seriam aquilo que Deleuze (1990 [2003]) chamou, a partir dos trabalhos de Foucault, de "Sociedade do controle". Aí, os dispositivos de vigilância e controle eletrônico, graças à numerização da memória, têm tendência a recuperar os traços da vida dos sujeitos, para utilizá-los com distintos fins.

As problemáticas deste artigo são de diversas ordens. Inicialmente nos indagamos se os condomínios se inscreveriam numa sociedade disciplinar ou numa sociedade do controle. A sociedade disciplinar, para Foucault (1991, 1979), era (é) constituída de meios: prisões, escolas, fábricas, vilas de operários, hospitais etc. Essa sociedade, que necessita(va) desses espaços de enclausuramento para a gestão dos modos de vida, continua a existir heterogeneamente, no entanto já desponta, há certo tempo, aquilo que Deleuze (2003) chamou - em referência a Foucault - de sociedade do controle. Esta não necessita mais dos meios de enclausuramento, porque um controle não é uma disciplina: podem-se construir espaços de circulação mais ou menos "livres", mas controlados por câmeras e guardas, como os shoppings, as autoestradas ou as fábricas, que não necessitam mais dum espaço onde se vigie a vida cotidiana dos trabalhadores como nas antigas vilas operárias. Há, por outro lado,

\footnotetext{
3 A Universidade Federal do Espírito Santo (Ufes) atualmente está levando adiante uma política dita de "segurança" generalizada que se traduz pela instalação, dentre outras coisas, em seus campi, de cerca de 1.000 câmeras por um custo anual do serviço superior a 4 milhões de Reais (cf. Gazeta on line, 29/09/2012). Podemos nos questionar sobre os custos e a eficácia de tal mecanismo, além, é claro, e, sobretudo, do clima de "controle" que viveremos dentro dum espaço em princípio destinado à liberdade de pesquisa, ensino e extensão.
}

Geo UERJ - Ano $14, n^{\circ} .23$, v. 2, $2^{\circ}$ semestre de 2012 p. 619-655

ISSN: 1415-7543 E-ISSN: 1981-9021

http://www.e-publicacoes.uerj.br/index.php/geouerj 
as "palavras de ordem" que servem para "informar" e tentam formatar as consciências dos trabalhadores. A imprensa em geral "informa" e comunica aos cidadãos sobre aquilo que se deve pensar, apreciar e em que se deve crer. Os acúmulos de controles, com informações digitais sobre a vida cotidiana dos cidadãos (compras, situação bancária, vida etc.) se multiplicam e o domínio à distância por GPSs, os mais diversos possíveis, se instaura. $\mathrm{O}$ controle estaria à distância e na gestão de fluxos que se supõem livres.

Em qual dos dois modos (disciplinar ou controle) inscreveríamos o incremento dos modos de habitar coletivos murados nas cidades? Seriam os condomínios um resquício das sociedades disciplinares que disciplinariam a vida dos cidadãos, formatando-os e fabricando uma raça dum novo tipo de citadino, num reaparecimento dum passado que se acreditava moribundo? Ou um modo de habitar do tipo sociedade do controle, onde não necessariamente se desejaria impor disciplina, mas seduzir por meio de palavras de ordem (tranquilidade, "segurança", paz, verde etc.) vendidas com o hábitat? Forma de "solução escapista" e elitista às questões prementes da segurança e violência da sociedade brasileira (SOUZA, 2008)? Espaços de "novo estilo" destinados à acumulação da renda da terra ligada à "nova onda" da financiarização e a um viver entre iguais? Ou ainda seriam esses agregados uma mescla de disciplina e de controle no sentido de Foucault (1988)? Ou um agenciamento coletivo de todos esses aspectos na associação dum espaço interno a um espaço externo, um fora e um dentro que, juntos, atravessariam as subjetividades e construiriam pragmaticamente um "novo-velho mundo" banhado na cultura do vazio e da aparência sobre um fundo de valorização imobiliária, de discursos securitários e de retorno a um ideal comunitário? Assim, os condomínios estariam transformando-se no horizonte irremediável de nossa época? Estaríamos assistindo ao que Soja (2010 [2000]) chamou, a propósito da multiplicação de subúrbios em Los Angeles, de "Urbanicídio" das cidades?

A partir dessas questões, tentamos entender os vários aspectos (legais, urbanos, ambientais e de vida cotidiana) desses construtos socioespaciais que são os hábitats enclausurados. Para tal, estudamos a sua proliferação no Município de Serra, integrante da Região Metropolitana da Grande Vitória (RMGV), no Espírito Santo. Nosso objetivo, inicialmente, foi o de mapear os condomínios. Assim, analisaram-se suas tipologias e as estratégias de expansão da mancha urbana a eles associadas. Em seguida, estudamos, para exemplificar nossas problemáticas, três tipos de condomínios representativos desse tipo de hábitat: o Alphaville, o Boulevard Lagoa e o Monte Verde, a partir de dados associados ao Condomínio Aldeia de Laranjeiras, estudado anteriormente.

Geo UERJ - Ano 14, nº. 23, v. 2, $2^{\circ}$ semestre de 2012 p. 619-655

ISSN: 1415-7543 E-ISSN: 1981-9021

http://www.e-publicacoes.uerj.br/index.php/geouerj 
Dois desses condomínios são, em realidade, loteamentos fechados - ilegais, segundo a legislação federal em vigor, mas autorizados pela Prefeitura Municipal de Serra (PMS), respaldada em Lei municipal - pois os futuros moradores compram os terrenos, equipados, com infraestrutura, mas devem construir suas próprias casas, segundo um padrão definido pelos empreendedores. Os lotes são destinados às camadas sociais dominantes e médias superiores. Um desses empreendimentos representa uma "marca" consagrada no Brasil, um "estilo": o Alphaville, localizado numa área de preservação ambiental próxima à Baía de Vitória, perímetro de expansão da mancha urbana da RMGV; está em fase de finalização e conta ainda com poucos moradores. Na RMGV, o topônimo desse hábitat fechado faz referência à fazenda da região onde se instalou: a Fazenda Jacuhy. O outro, o Boulevard Lagoa, é uma promoção duma empresa local associada a uma incorporadora nacional; localiza-se próximo à Lagoa Jacuném, igualmente área de proteção ambiental. Em ambos, até o primeiro semestre de 2012 ainda havia poucos moradores, pois as casas estavam em construção. O terceiro caso, o Monte Verde, é um conjunto de casas geminadas de cerca de $75 \mathrm{~m} 2$, vendidas prontas e dotadas, igualmente, de área de lazer. Este se situa numa zona mais densamente povoada e de aceleração rápida da ocupação do solo; seus moradores representam as categorias sociais do que se pode chamar de "classe média" clássica: funcionalismo público, comerciantes, pequenos e médios empreendedores, profissões liberais etc. Utilizamos algumas informações relativas ao Condomínio Aldeia de Laranjeiras, estudado precedentemente, para complementar nossas análises sobre a vida cotidiana nos condomínios em apreço.

Esta pesquisa se fez em diversas etapas. Inicialmente, realizamos um levantamento dos condomínios projetados, aprovados, em lançamento, em construção e habitados, em Serra, por meio de inúmeros trabalhos de campo entre 2008 e 2012. Esse levantamento foi complementado por entrevistas semiestruturadas, efetuadas com representantes de algumas Imobiliárias envolvidas na venda desses condomínios, bem como com representantes da secretaria municipal de obras e de desenvolvimento urbano da PMS. Utilizamos, igualmente, as propagandas dos empreendimentos e informações disponíveis nos sites das empresas e do Censo anual do Sindicato da Construção Civil do Espírito Santo (Sinduscon-ES).

Os estudos de casos desses quatro condomínios foram efetuados entre 2009 e 2012 . No condomínio Aldeia de Laranjeiras - o primeiro constituído de casas, edificado no Município de Serra - invocado neste artigo de maneira não central, pois foi analisado noutro momento, residia um membro de nossa equipe de pesquisadores. Isso nos facilitou o acesso e a 
realização duma série de entrevistas formais e informais (tendo um roteiro pré-estabelecido), com 5 moradores e o síndico. Realizamos três visitas ao local e tivemos, também, acesso aos registros em livro das reclamações cotidianas dos habitantes. O condomínio Vila Verde foi estudado em duas ocasiões em 2011 e 2012. Tivemos acesso a ele graças às relações pessoais com alguns de seus moradores, que nos permitiram realizar 5 entrevistas; visitamos o condomínio em três ocasiões. Nesses condomínios, além da forma do hábitat, da localização, do aparato de segurança e de lazer, buscamos entender a vida cotidiana: a relação com a vizinhança, as motivações para ali morar, a participação na vida "comunitária" do condomínio, os usos dos espaços comuns, os conflitos etc.

A pesquisa sobre o Alphaville Jacuhy e o Boulevard Lagoa se centrou sobre sua forma, estrutura e função espaciais, seu processo de aprovação e seus impactos ambientais e arqueológicos, visto que estão em fase de implementação. Para isso, realizamos entrevistas com responsáveis locais pelos empreendimentos, com funcionários da PMS e de Vitória e do Instituo Estadual de Meio Ambiente (Iema), que trabalharam nos relatórios de aprovação. Foram lidos e interpretados os Relatórios de Impactos Ambientais, a legislação urbana e ambiental que diz respeito às áreas onde esses empreendimentos se instalaram, além, é claro, de diversos trabalhos de campo nos condomínios entre 2011 e 2012.

\section{A EXPLOSÃO DOS CONDOMÍNIOS EM SERRA}

Condomínios fechados e loteamentos ultimamente vêm sendo abordados como sinônimos, entretanto há diferenças formais e legais entre ambos. O loteamento é regido pela Lei 6.766/79 (BRASIL, 1979), que compreende o parcelamento do solo para fins urbanos. Em princípio, não pode ser fechado: deve ter infraestruturas e equipamentos, com acesso público, ligados às redes públicas. O condomínio, por sua vez, é regido pela a Lei 4.591/64 (BRASIL, 1964), que o considera uma propriedade única onde existem as "frações ideais" dos proprietários individuais" dentro dum espaço (em geral, de prédios) que não se inscrevem no espaço público. No entanto, na prática os fatos não são tão distintos, pois há uma flexibilização do termo "condomínio fechado". Todos os conjuntos imobiliários murados, que possuem alguns itens de lazer são denominados (ora pela mídia, ora pelos empreendedores) condomínios fechados, o que também favorece a transgressão das leis, como no caso de Serra, onde a Câmara Municipal aprovou uma lei autorizando o "Município a conceder o direito real de uso resolúvel de áreas públicas de loteamentos". Assim, se admitiram "loteamentos com perímetro fechado", permitindo o uso privativo de “áreas públicas (parques, praças, áreas verdes, espaços livres e áreas reservadas para Geo UERJ - Ano 14, no ${ }^{\circ} 23$, v. 2, $2^{\circ}$ semestre de 2012 p. 619-655

ISSN: 1415-7543 E-ISSN: 1981-9021

http://www.e-publicacoes.uerj.br/index.php/geouerj 
equipamento urbano" (PMS-ES, 2008). Por meio desse malabarismo se concede o percentual de $35 \%$ de área a ser loteado, que deveria pertencer ao domínio público, conforme previsto em lei, para o "uso privativo dos proprietários do loteamento". Mas, paradoxalmente, essa privatização do que deveria ser espaço público não dispensa a inserção nas redes públicas de eletricidade, de esgoto e de água, bem como a proximidade das redes de transportes, como veremos (ZANOTELLI et al., 2009; 2010).

A RMGV, composta de 7 Municípios, dos quais 4 formam uma conurbação, que é o centro da região (Vitória, Serra, Vila Velha, Cariacica) - a esses se somam os Municípios de Viana, Guarapari e Fundão - viveu nas últimas décadas um acelerado processo de expansão. De 1980 para cá, sua população cresceu $126 \%$, passando de 744.744 habitantes para os atuais 1.685.770 habitantes (IBGE, 2010), que hoje representam 48\% da população do Espírito Santo. A população de Serra se destaca com o maior crescimento da Região (396\% no período), passando de 82 mil a 409 mil habitantes. É o segundo Município mais povoado do Espírito Santo, com população superior à da própria capital (Vitória), mas com uma densidade de 740 habitantes/Km²: a menor dos Municípios conurbados da RMGV. Serra se transformou nos últimos 30 anos, passando a ser um Município industrial (polo portuário e siderúrgico de Tubarão) e urbano, mas ainda com uma área rural importante, composta de várias grandes fazendas (56\% de sua área são de espaços rurais).

Esse crescimento populacional de Serra se deu de maneira fragmentada, no entorno das vias sobre os platôs e seus abordos, bem como nos fundos de vale, nas encostas e na orla marítima. A urbanização (sobretudo com a expansão de conjuntos habitacionais do Banco Nacional da Habitação, construídos nos anos 1970-1980) avançou sobre os espaços a proteger, transformando várias fazendas antigas em loteamentos e provocando amplos impactos socioambientais. Contando, ainda, com muitos "espaços vazios" e "livres" sob a pressão do movimento especulativo dos loteamentos e condomínios fechados, o Município se tornou um dos principais territórios dos investimentos imobiliários do Estado no início do século XXI. Entre 2003 e 2009, houve, segundo o Sinduscon-ES, uma expansão de $3.000 \%$ das construções de imóveis em Serra. Somente na região de Laranjeiras - centro econômico e comercial em torno do qual se localiza a maioria dos lançamentos imobiliários - havia 11.507 imóveis em obras em 2011: a maioria de condomínios verticais (RIBEIRO, 2011, p.73-74). Até 2003, o Município acolhia majoritariamente empreendimentos fechados horizontais, sobretudo conjuntos habitacionais e loteamentos tradicionais. A partir de 2006, a produção vertical aumentou, atingindo seu apogeu em 
2008, com 45 empreendimentos (cf. Gráfico 1, ilustrando 134 empreendimentos aprovados, em análise, em lançamento, em construção e entregues até 2009).

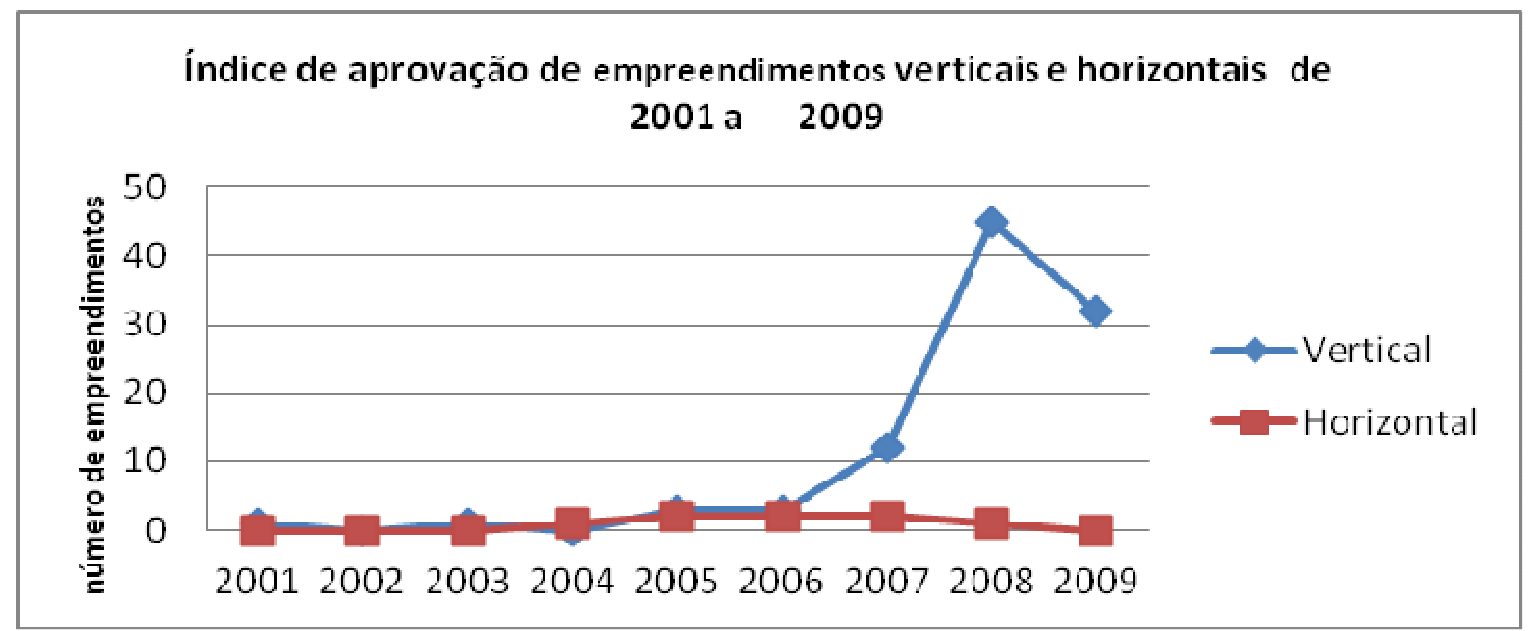

GRÁFICO 1: NÚMERO DE EMPREENDIMENTOS VERTICAIS E HORIZONTAIS APROVADOS PELA PMS DE 2001 A 2009.

Fonte: PMS e trabalho de campo.

Conforme levantamento relativo ao período de 2001 a 2009, Serra apresentava 156 empreendimentos - em lançamento, em estágio de construção, entregues e aprovados e/ou em análise pela PMS, destinados, principalmente, às camadas "médias" da sociedade, incluindo os beneficiários do Programa Minha Casa, Minha Vida, que está voltado, majoritariamente, por enquanto, para os que recebem entre de 3 e 6 salários mínimos. ${ }^{4}$ Tais empreendimentos são de natureza fechada, e se distribuem por diferentes bairros. Por um lado, essa expansão se deu em função da relativa disponibilidade de terras no Município e da consequente rarefação dos espaços "livres" na capital do Espírito Santo, Vitória, bem como da redução desses espaços na região de Praia da Costa e orla do Município de Vila Velha, onde moram as classes médias e dominantes. Por outro, essa expansão se deu em função da presença no Município (como em outros lugares) de grandes empresas nacionais e internacionais do setor imobiliário. Empresas que buscam fazer investimentos em "novos produtos residenciais" - os condomínios fechados - na RMGV.

\footnotetext{
${ }^{4}$ O Programa Minha Casa, Minha Vida prevê entre 2009 e 2014 construir 2 milhões de habitações, sendo que 1,2 milhão para os níveis de renda de até 3 Salários Mínimos. No entanto, até a presente data, somente 1/3 do que foi contratado (em projeto, em construção ou já entregues até setembro de 2012) é relativo a essa faixa da população (313 mil imóveis sobre 954 mil contratados) que têm imóveis fortemente subsidiados pelo Tesouro Federal e cujos preços máximos, para a faixa de renda até 3 Salários Mínimos, indicados pelo governo para os empreendedores está limitado a $\mathrm{R} \$ 65$ mil para apartamentos e $\mathrm{R} \$ 63$ mil para casas. Valores que - em função da elevação dos preços da terra e do custo do material de construção e dos lucros dos construtores - estariam defasados segundo os empreendedores. Assim, muitos dos projetos têm dificuldades a serem concretizados e os que o são se localizam, por boa parte, nas periferias das cidades - com preços de terrenos mais acessíveis ou mesmo doados pelas prefeituras - onde não há nenhuma espécie de serviços e equipamentos (ver a esse propósito a Folha de São Paulo, p. C3, 21 de outubro de 201)..
}

Geo UERJ - Ano 14, $\mathrm{n}^{\circ} .23$, v. $2,2^{\circ}$ semestre de 2012 p. 619-655

ISSN: 1415-7543 E-ISSN: 1981-9021

http://www.e-publicacoes.uerj.br/index.php/geouerj 
Em 2009, sobre os 156 empreendimentos invocados precedentemente, 82 pertencentes a 19 empresas distintas, estavam efetivamente em lançamento (18\%); em construção, 49\%; e entregues, 33\%. Isso significa que 74 empreendimentos ainda se encontravam até recentemente na forma de projetos, podendo ou não se realizar. É provável que esse número de projetos aprovados ou em análise na PMS seja uma estratégia dos empreendedores para se posicionarem no mercado, uma vez que as áreas aprovadas para a construção acabam funcionando como reserva de valor à espera da evolução do mercado. Apenas a empresa Cyrela Brazil Realty ${ }^{5}$ possuía 24 empreendimentos aprovados, no entanto apenas 14 estavam em lançamento, em construção e entregues.

A valorização progressiva do $\mathrm{m}^{2}$ dos condomínios em Serra entre 2003 e 2009 se observa no gráfico 2, traduzindo o interesse do setor imobiliário pelas terras do Município. No entanto, a partir da evolução recente do mercado, em função da crise econômica iniciada em 2008 e de seus efeitos sobre a economia brasileira, interrogamo-nos sobre uma eventual desvalorização imobiliária na RMGV, em particular em Serra ${ }^{6}$. Tem-se notado que diversos imóveis construídos, sobretudo em prédios, com apartamentos modestos, vêm ficando ostensivamente vazios na região de Laranjeiras. Porém o programa Minha casa, minha vida, tem dado alento ao setor da construção civil. Muitos projetos hoje, em Serra, estão voltados para esse mercado. Agora, o setor subvencionado desse programa foi atendido em uma de suas reivindicações: o governo aumentou os limites do financiamento, passando de 150 mil reais para 170 mil reais.

Em 2010, Serra era o Município que tinha mais contratações junto à Caixa Econômica Federal (CEF) do programa Minha casa, minha vida: 37\% dos imóveis (3.974 unidades) desse programa em financiamento no Espírito Santo, concentrados, essencialmente, na categoria 3 a 10 salários mínimos (61\% dessa categoria no Estado estão em construção em Serra), conforme dados fornecidos em palestra na Ufes, em 2010, pelo Diretor Regional da CEF. Esse volume representa mais de 1/3 do setor imobiliário em construção na Região de Laranjeiras em 2011. E, é bom lembrar: a maioria das edificações do programa Minha casa, minha vida é dotada das "virtudes" do condomínio fechado, mesmo que de maneira

\footnotetext{
${ }^{5}$ Cyrela Brazil Realty no Espírito Santo atua na incorporação de empreendimentos da empresa Morar, Incortel, e, por fim, da Living, que vem oferecendo ao mercado condomínios inseridos no programa Minha Casa, Minha Vida, do governo Federal.

${ }^{6}$ A demanda tem caído desde 2009. O "Índice de velocidade de vendas" na Grande Vitória tem ficado abaixo do esperado. Assim, em agosto de 2012, sobre 4.212 unidades residenciais em venda, somente 257 tinham sido vendidas na região, ou seja, $6,1 \%$ do total. O índice "ideal", segundo os profissionais do setor, é que o indicador se situe entre $8 \%$ e $12 \%$. Para complicar o fato, 35 mil unidades estão ainda em construção. (cf. jornal A Gazeta, 01 out. de 2012, p.37).

Geo UERJ - Ano $14, n^{\circ} .23$, v. 2, $2^{\circ}$ semestre de 2012 p. 619-655

ISSN: 1415-7543 E-ISSN: 1981-9021

http://www.e-publicacoes.uerj.br/index.php/geouerj
} 
mais modesta, com qualidade de construção que deixa a desejar: área de lazer, guarita na entrada dos conjuntos, controles diversos etc. Sobre a anticidade que vários desses conjuntos do programa Minha casa, minha vida podem tipificar, muitos construídos em lugares sem infraestrutura, sobretudo aqueles destinados às famílias mais modestas, com renda de até 3 salários mínimos e onde está o déficit habitacional brasileiro, pode-se ler Maricato (2011). Um caso típico que exemplifica o que foi invocado a propósito do programa Minha casa, minha vida, é o conjunto habitacional Vista Bela localizado no Norte do Paraná, bem longe do centro de Londrina, com uma população de 12 mil habitantes, vivendo em 2.712 moradias: 1.272 casas geminadas de $35 \mathrm{~m} 2$ e 1.440 apartamentos de $42 \mathrm{~m} 2$. A população não tem escola, creche, nem posto de saúde, muito menos comércio formal (Cf. Folha de São Paulo, p. C1, 21 de outubro de 2012).

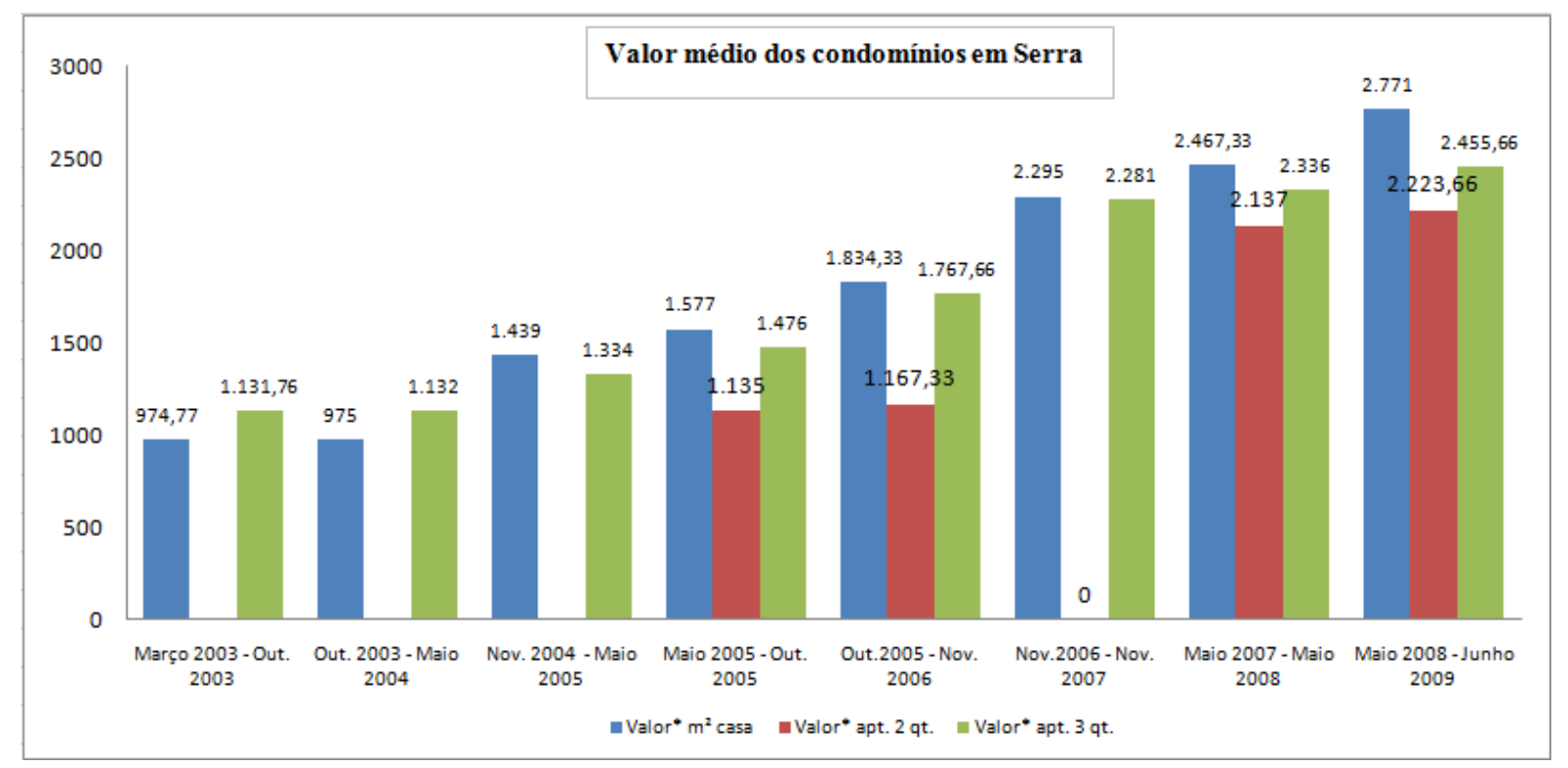

GRÁFICO 2: VALOR MÉDIO DO M² DAS RESIDÊNCIAS NOS CONDOMÍNIOS FECHADOS EM SERRA $2003-2009$.

Fonte: Sinduscon, 2003 a 2009, adaptado por Francismar C. Ferreira.

A localização e distribuição dos condomínios e loteamentos fechados no espaço de Serra se estendem por distintos bairros: uns próximos a Vitória; outros, ao bairro Laranjeiras; e, outros, próximos aos meios naturais sensíveis ou importantes vias de circulação (Figura 1). 


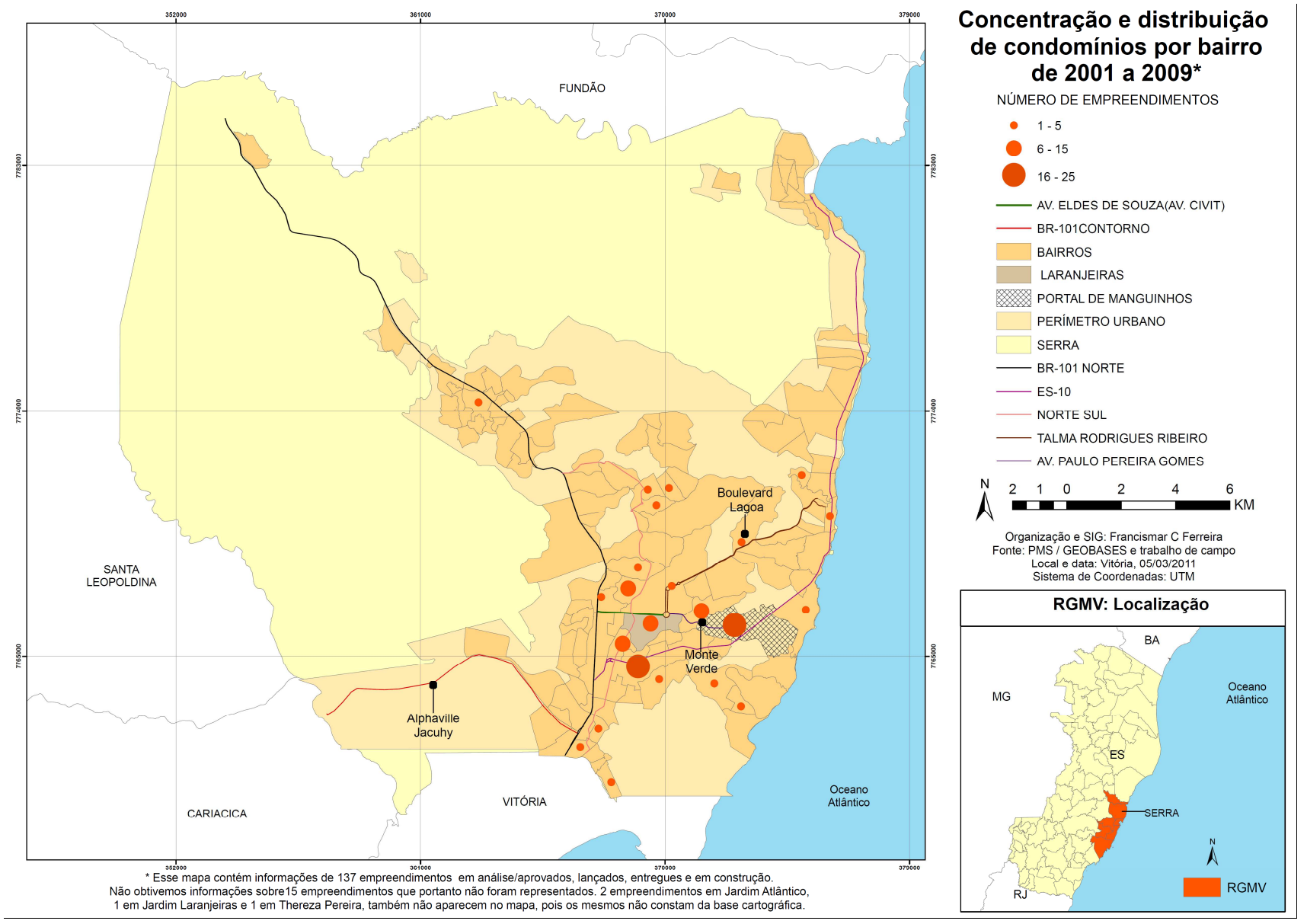

Figura 1: Concentração e distribuição dos condomínios e loteamentos fechados por Bairro (2001-2009).

Condomínios e loteamentos fechados vêm materializando-se em Serra em decorrência dos interesses públicos e privados. Esses investimentos, por um lado, no espaço e no território, atendem à pretensão de a administração pública "mudar o perfil de seus habitantes para uma população de mais alta renda", conforme o declara em entrevista que nos foi concedida em 2009, a secretária de Desenvolvimento Urbano de Serra. Por outro lado, esse discurso - para além do preconceito evidente com os habitantes mais pobres - implica outro encobrimento que deve ser mais bem estudado: as ambições tanto dos setores empresariais ligados à construção civil e ao mercado imobiliário como dos proprietários de terras localizadas no perímetro rural do Município.

Em Serra, o perímetro rural $\left(310 \mathrm{Km}^{2}\right)$ corresponde a aproximadamente $56 \%$ da área total do Município $\left(553 \mathrm{Km}^{2}\right)$. Cerca de $47 \%$ da área rural estão - se os dados o IBGE (2006) estiverem corretos - nas mãos de três proprietários fundiários. No censo, não se especifica individualmente o tamanho dessas propriedades. Ou seja, dos $310 \mathrm{Km}^{2}$ rurais do Município, aproximadamente $145 \mathrm{Km}^{2}$ (14.500ha! verdadeira Sesmaria equivalente a duas vezes a área 
do Município de Vitória, que tem $73 \mathrm{Km}^{2}$ ) pertencem a três proprietários. Há uma fazenda onde está localizado o empreendimento Alphaville tão vasta que se estende da região histórica de Queimado até ao Contorno metropolitano da BR 101: cerca de 10Km em linha reta! Desse modo, com todos os projetos previstos na região, como a estrada do contorno da Área de Proteção Ambiental do Mestre Álvaro, a área será privilegiada, com a modificação da afetação das terras, que poderão se inscrever no perímetro urbano e, conseguintemente, se valorizar.

A renda esperada da terra que, em princípio, é um bem coletivo, foi analisada por Marx (1988). Esse é um dos aspectos que acentuam relativamente os preços dos imóveis, em período normal. Por meio da extração da renda relativa e absoluta, os proprietários associados aos incorporadores - extraem sobrelucro do mercado. Assim, “(...) o monopólio da propriedade fundiária é um pressuposto histórico e continua sendo o fundamento permanente do modo de produção capitalista” (MARX, 188, p.112-113). Mas, em período de crise, como aquela dos subprimes, em 2008, viu-se a realidade dos fatos: os preços das terras, em particular das terras urbanas e dos imóveis, subiram artificialmente por meio da titrização generalizada dos ativos imobiliários, os subprimes, nos Estados Unidos, e, em seguida, desabaram nas bolsas (HARVEY, 2011). Muitos desses processos têm a ver com o Estado indulgente, que permite a apropriação privada dos espaços e não regula a expansão dos interesses imobiliários e monopolistas de solos. Tais interesses se servem dos melhores terrenos, paisagens e acessos, para aumentar os preços de venda. Feitas essas considerações, passamos aos condomínios estudados.

\section{OS CONDOMÍNIOS FECHADOS}

Analisamos, no Alphaville e no Boulevard Lagoa, a relação ambígua entre o Estado e o setor privado por meio das autorizações legais e apoios diversos por parte dos organismos públicos e prefeituras a esses empreendimentos. Há nisso uma contradição constante e flagrante com as leis que regem o uso e a ocupação do solo, bem como com as leis ambientais. Sobressaem, também, nas análises, os interesses que subentendem a especulação e a extração de rendas da terra no espaço urbano ou nas franjas do rurbano. Avaliamos, igualmente, as referências à segurança e à insegurança como justificativas para a construção desses condomínios. Os discursos de insegurança manifestam, por um lado, uma situação real de violência mais grave, que atinge, sobretudo, as camadas mais pobres da sociedade, e, por outro lado, os fantasmas coletivos do medo difundidos pela imprensa e pelos agentes interessados na produção do pânico como moeda de valor. Por fim, no estudo de caso do Geo UERJ - Ano $14, n^{\circ} .23$, v. 2, $2^{\circ}$ semestre de 2012 p. 619-655 
condomínio Vila Verde se buscou observar a vida cotidiana, os aparatos de controle e a organização espacial dum condomínio de "classe média", resgatando algumas temáticas notadas na investigação dos dois primeiros condomínios e complementando-as com uma pesquisa que realizamos, antes, sobre o condomínio Aldeia de Laranjeiras.

A partir da experiência americana Blakely e Snyder Apud Soja (2000 [2008], p.442) fizeram uma classificação identificando três tipos de comunidades fechadas: comunidades de estilo de vida (comunidades de retiro, de golfo, de ócio e os novos povoados suburbanos); comunidades de prestígio (reservadas para os mais ricos, famosos e os executivos); comunidades de zonas de segurança (construídas, em princípio, sobre o medo do crime e dos estranhos, divididas em três aspectos distintos: cidade, subúrbio e barricadas, esta última concentrada nas áreas mais pobres). Os dois primeiros exemplos que exporemos se inscreveriam nas "comunidades de estilo de vida e de prestígio", o terceiro se situaria nas "comunidades de zonas de segurança". Essas comunidades seriam o que Mike Davis (Apud SOJA, Op. cit.) chama de "revolução fortificada" das cidades nos Estados Unidos.

\section{ALPHAVILLE}

O Alphaville se iniciou em 2006; ocupa uma área de aproximadamente 244ha, cercada por muros; conta com 1903 lotes residenciais, 106 comerciais e 21 empresariais. Essa área ambientalmente frágil não apresenta continuidade com a malha urbana; ali se encontram planícies suscetíveis a alagamentos, manguezais e restinga. O lugar tem uma qualidade paisagística ímpar: próximo à Baía de Vitória, tem uma vista excepcional sobre o maciço costeiro do Mestre Álvaro, com 833m de altitude. Nessa paisagem, potencializada pelo fato de a região ter sido, no passado, ocupada por aldeias indígenas e fazendas jesuítas, há sítios arqueológicos pré-históricos e históricos. Os lotes residenciais têm dimensões variando entre $460 \mathrm{~m}^{2}$ e $735 \mathrm{~m}^{2}$. O valor médio do metro quadrado é de 410 reais (o preço dum lote varia entre 188 mil e 301 mil reais). Atualmente, já foram lançados 1.277 lotes, entre residenciais, comerciais e empresariais. Esses lotes correspondem às fases 1, 2 e 3; falta ainda a fase 4, que está em processo de licenciamento (Figura 3). Cada fase possui uma portaria, logo funciona como um condomínio diferente que se tem dentro dos muros do loteamento, entretanto, o clube de lazeres do empreendimento, construído pela empresa Alphaville S.A., é de uso de todos os residentes. O empreendimento, que está cercado de muros, conta com torres de vigília na entrada e é equipado com câmeras e pessoal de segurança (sobre isso e sobre o Alphaville de São Paulo, ver Caldeira, 2000). 
Dos lotes residenciais lançados, $85 \%$ já foram vendidos, bem como 55\% dos lotes empresariais e comerciais. Nenhum serviço comercial ou empresarial está sendo construído ainda, no entanto já existiam, em 2012, no primeiro semestre, 26 casas em construção e uma pronta, com morador. A aprovação do loteamento foi e é problemática, pois não obedeceu ao que prescrevem as diferentes leis de uso e ocupação do solo, leis ambientais e do patrimônio histórico e cultural.

A base para autorizar loteamentos fechados que de fato se transformam em condomínios fechados é uma lei municipal, que, como vimos, é ilegal em face da lei maior, federal. Além disso, a PMS (2010) sancionou a Lei 3.592 de 2010, que autoriza o poder executivo municipal a conceder o direito real de uso de imóveis do Município à associação Alphaville Jacuhy, tornando, assim, legítimo, o cercamento de vias públicas, áreas verdes e praças. Tal Lei permite que os $35 \%$ da área do loteamento, que deveriam ser doados para a PMS em cumprimento da Lei 6.766/79 de parcelamento do solo (BRASIL, 1979), sejam cercados pelo loteamento, deixando seu uso restrito aos futuros residentes. Além disso, a aprovação do Alphaville em Serra está em flagrante oposição ao que estipula o Plano Diretor Municipal (PDM) e o Plano Estratégico Municipal - Serra XXI (2008) - no que se refere à densificação dos espaços urbanos, isso porque o condomínio não apresenta continuidade alguma com a malha urbana.

Os desrespeitos às leis continuam na esfera estadual. A Lei estadual 7.943/2004 (ESPÍRITO SANTO, 2004), que rege o parcelamento do solo, não o permite em área de alagado, em terrenos de mangue e em áreas de sítios arqueológicos, antes dum parecer favorável do órgão estadual responsável, o Iema. Segundo um servidor da secretaria de meio ambiente da Prefeitura Municipal de Vitória (PMV), para obedecer a essa diretiva o Iema deveria ter avaliado os impactos do empreendimento. Entretanto, esse Instituto se pronunciou por meio dum parecer que não participou no processo de licenciamento ambiental do empreendimento, posto que a PMS seria a responsável pela tramitação. Notase, com isso, que não há uma política articulada entre as municipalidades e o Estado. Em face disso, a aprovação do Alphaville Jacuhy vem sendo feita graças ao desrespeito aos procedimentos indicados pelas leis existentes. Para além do parcelamento do solo, o empreendimento apresenta outras ambiguidades em seu processo de aprovação. Isso se verifica quando se analisam os impactos causados por obras de aterro e terraplanagem nos sítios arqueológicos registrados na área em questão, cujo solo é um ambiente de depósitos sedimentares de origem fluvial e marinha, que permitiu a constituição duma grande 
quantidade de sambaquis. Assim, por meio de estudos sobre um sambaqui (Sítio Areal) localizado nas proximidades do Alphaville Jacuhy, ao Norte da baía de Vitória, o arqueólogo Celso Perota (2007, p. 160 e 161) identificou dados sobre uma transgressão e uma regressão marinha.

[...] A população (indígena) que iniciou a construção do sítio chegou ao local num período de uma transgressão marinha. Essa transgressão possibilitou alterações na paisagem com o aparecimento de lagunas na região e o estabelecimento do sítio foi em função dessa geodinâmica, pois está localizado ao lado de uma paleolaguna, que foi a fonte dos recursos alimentares do grupo. Em seguida, ocorreu uma regressão e os padrões culturais no sítio mudam consideravelmente e existem indícios de uma agricultura incipiente.

Salles Cunha (1959) identificara ali uma alta densidade de sambaquis numa pequena área; a realização das obras do Alphaville Jacuhy coloca em evidência essa concentração. Somente na área do empreendimento, determinaram-se, por prospecção, 48 pontos de ocorrências arqueológicas: são sambaquis compostos por materiais líticos (rochas trabalhadas como batedores, machados de pedra e outros), conchas, material faunístico, culturais, históricos e ossos humanos, apresentando significativas elevações em relação ao entorno. Na Figura 2, os sambaquis na RMGV, nos arredores da baía de Vitória.

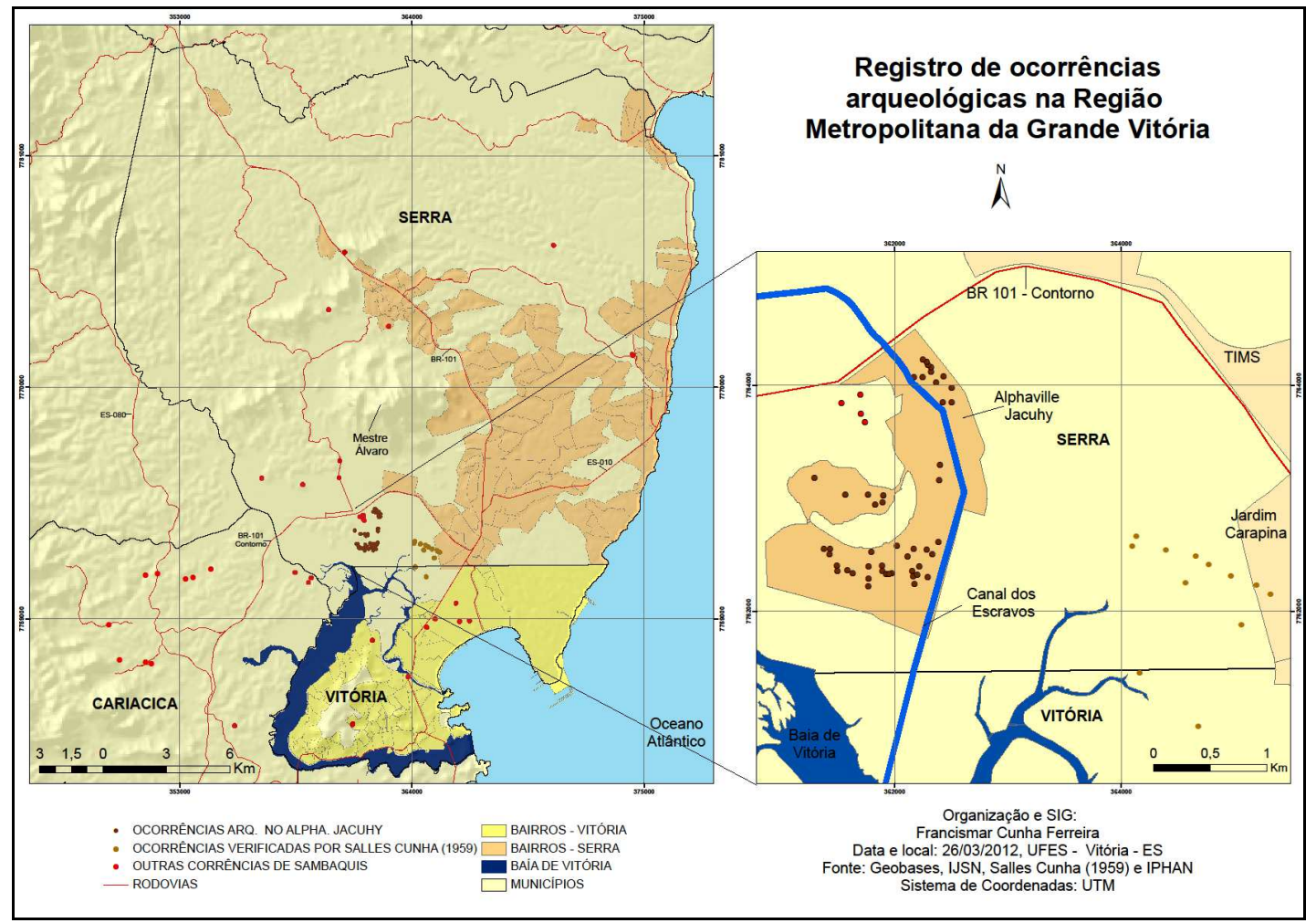

Figura 2: Registros de ocorrências arqueológicas na RMGV. 
Os 48 pontos de registros arqueológicos identificados na área do Alphaville Jacuhy foram subdivididos em 23 áreas de ocorrências. Dessas, apenas 11 foram "resgatadas"; outras 10 estão sendo monitoradas; uma foi destruída; e uma qualificada unicamente como fora da área, como se vê na Figura 3.

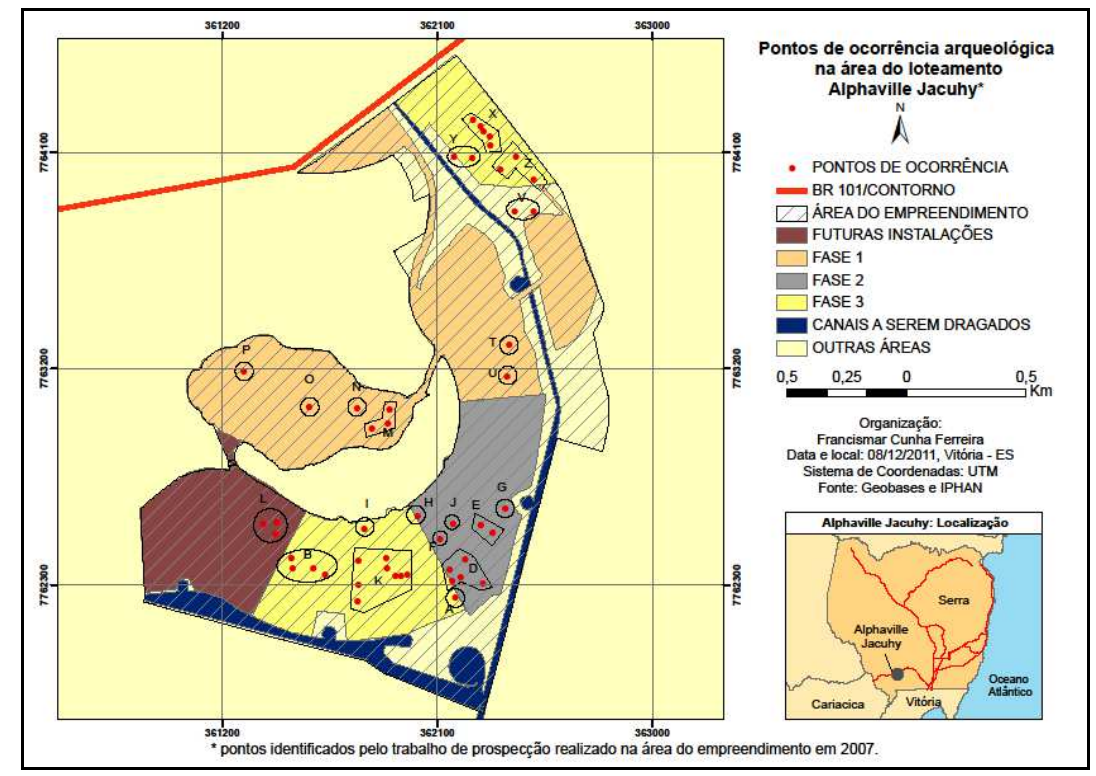

Figura 3: Áreas de ocorrências arqueológicas no empreendimento Alphaville Jacuhy.

Segundo o IPHAN, esses materiais arqueológicos foram retirados do local para estudos. Atualmente, estão no Rio de Janeiro, pois o Espírito Santo não possui um local onde se possa alocá-los. O Alphaville, por sua vez, lançou um projeto de criação duma modesta sala, chamada de "museu", no local do loteamento, onde funcionaria um projeto educacional desenvolvido pela Fundação Alphaville. Parte deste projeto seria o desenvolvimento de atividades educacionais relacionadas aos aspectos arqueológicos e ambientais do sítio. Esse espaço, em linhas gerais, acabou funcionando como uma "compensação" que o empreendimento repassou aos órgãos públicos, que por sua vez, permitiram a apropriação, destruição e o "salvamento" dos sítios arqueológicos.

Ao relacionarmos esses episódios com algumas leis sobre sítios arqueológicos, nota-se que a implantação do empreendimento está na contramão do que elas preconizam. Assim, segundo a Lei federal 3.924/61 (BRASIL, 1961), que dispõe sobre os monumentos arqueológicos e pré-históricos, são proibidas quaisquer práticas que ocasionem a destruição ou mutilação de sambaquis. Entretanto, verificam-se, no caso do Alphaville, algumas áreas com significativos registros serem destruídas com obras de aterro e terraplanagem, a exemplo do Residencial Colina (Fase 1), local onde havia ocorrência de 
sambaquis (ver no mapa da Figura 3 as áreas de ocorrências M, N, O e P). Ali, a empresa Alphaville escavou e desmontou uma colina, "resgatando" parte dos materiais. Atualmente, segundo um corretor de imóveis do empreendimento, ela tem $16 \mathrm{~m}$ de altura a menos. Qual foi o percentual de material resgatado em relação ao que ali existia? Como se realizou e qual a qualidade desse resgate? São perguntas, por enquanto, sem respostas.

Segundo a Portaria 07 de 1998 do IPHAN (BRASIL, 1998), para obter permissão para a realização de escavações a fim de resgate, o empreendedor deve apresentar projetos e alternativas de máximo aproveitamento do potencial científico, cultural e educacional. O Alphaville construiu uma sala reservada para a "guarda" dos resquícios resgatados. Contudo, parte do material arqueológico pode ter sido destruída e aterrada. Sendo assim, o máximo aproveitamento do material para pesquisas científicas, para fins culturais e educacionais pode não ter sido realizado. Como consequência disso, a história e préhistória indígena acabam sendo enterradas em proveito dos interesses imobiliários. Destrói-se, assim, a paisagem, conjunto geocultural de significativa importância e beleza.

Em síntese, a PMS, a PMV, o governo do Estado e o IPHAN vêm permitindo a implantação do Alphaville de maneira a não respeitar minimamente os princípios estabelecidos nas leis. E o pior: vem favorecendo o proprietário fundiário e uma incorporadora que colocam em valor, simbolicamente - pois que materialmente parcela do sítio foi destruída - um sítio histórico e pré-histórico para desfrute dos felizes proprietários que se encontram diante de uma paisagem monumental e rara, o que faz subir seu valor na bolsa imobiliária pelo simples fato de possuir sobre ela o monopólio de uso legitimado pelo Estado. Sobre essa relação ambígua com as leis e a função legitimadora do Estado nas relações de poder estabelecidas na sociedade capitalista, podemos nos reportar a Foucault (1976), bem como a Marx (1988). Passaremos, agora, a descrever o outro condomínio fechado, Boulevard Lagoa.

\section{BOULEVARD LAGOA}

O loteamento Boulevard Lagoa localiza-se entre a Lagoa Jacuném e a Avenida Talma Rodrigues Ribeiro, no Município de Serra-ES, relativamente próximo ao bairro Laranjeiras. A seu lado, encontra-se o bairro popular Feu Rosa. No mapa da Figura 4, poder-se-á melhor visualizar os aspectos naturais onde está localizado. 


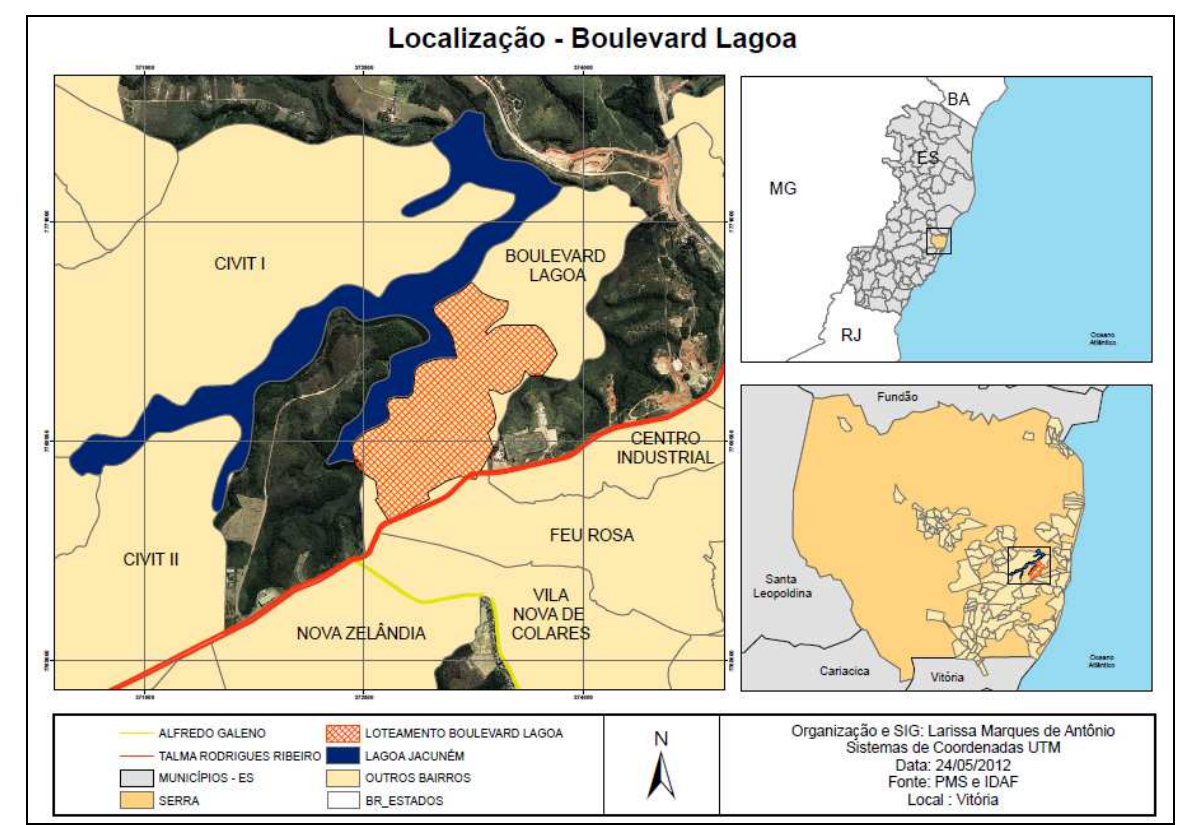

Figura 4: Boulevard Lagoa - localização

Boulevard Lagoa é o resultado da conjunção de duas empresas: a Cristal Empreendimentos Imobiliários e a Teixeira Hozmann S.A. Inicialmente, foi idealizado e parcialmente executado pela Jacuném Construções e Empreendimentos Ltda., em associação com a Cristal Empreendimentos Ltda., sendo a primeira a proprietária e a última a incorporadora. Esse loteamento tem 740 lotes divididos em 45 quadras. Além dos lotes (unidades unifamiliares), conta com uma área comercial exclusiva; um complexo aquático, com 5 piscinas; e várias áreas de esporte e lazer. Atualmente, segundo sua Corretora, já foram vendidos 75\% dos lotes; conforme o Censo do IBGE (2010), 23 pessoas o habitavam em 2010. O tamanho mínimo do lote é de 450m²; seu valor médio é 160 mil reais.

Iniciado há 20 anos, esse loteamento, no entanto, foi legalizado pelo Decreto municipal $\mathrm{n}^{\circ}$ 3.286 de 2006. Sua regularização - ademais, loteamento ilegalmente fechado e considerado "condomínio", localizado às margens duma lagoa que integra a única bacia hidrográfica estritamente municipal em Serra, protegida por legislação -, é, propriamente falando, uma contradição da mesma forma que o é a regularização do Alphaville.

O que demonstra, mais uma vez, a associação indevida entre a prefeitura e os empreendedores é o fato de que ainda quando o loteamento era irregular, em 1999, a PMS criou o "bairro" Condomínio Ecológico Parque da Lagoa, que englobava essencialmente uma área de propriedade privada, abrindo as portas para a possibilidade de se ter um "bairro privado", o que efetivamente ocorreria 10 anos mais tarde. Contando com uma área total de 74ha, o que deveria pertencer aos futuros moradores seria somente a área loteada 
(34ha), as áreas restantes (praças, áreas de lazer, equipamentos e infraestrutura e a área verde), teoricamente, ficariam sob a égide da prefeitura. Contudo, foi o próprio empreendimento que fomentou a Lei municipal n 3201 de 18/02/2008, que também serviu aos outros empreendimentos do Município, que autoriza cercar as infraestruturas e equipamento públicos para uso exclusivo dos proprietários. Assim, as áreas que legalmente deveriam se integrar aos logradouros públicos não o foram, pois o loteamento-bairro artificial é murado e é confrontante com a Lagoa Jacuném. Criam-se, portanto, duas barreiras: a primeira física (muro) e a segunda econômica, pois apenas acessarão esses equipamentos urbanos os que podem pagar para morar ali.

A PMS criou a Área de Preservação Ambiental (APA) da Lagoa Jacuném (Lei nº 2.135 de 25 de novembro de 1998) bem antes da regularização do loteamento que, como vimos, ocorreu em 2006. Apesar de a municipalidade alegar a intensão de proteger o contorno da lagoa, a APA permite que as áreas adjacentes a ela sejam incluídas na categoria de uso direto dos recursos naturais, o que, sob certas condições, possibilita determinados usos que impactarão a Área de Preservação Permanente (APP) da lagoa e de seu entorno. Esse espaço poderia - se houvesse, mesmo, interesse em sua preservação e frequentação por parte da população - ser transformado em parque, pois a qualidade paisagística e ambiental do sítio é de primeiro plano. De fato, o Boulevard Lagoa degrada a área e transforma a natureza em renda, com a cumplicidade dos agentes públicos. Para encobrir isso, um discurso presente nos relatórios técnicos e nas falas de alguns envolvidos no processo de aprovação do loteamento imputa a poluição e a degradação aos "outros" que moram num bairro popular próximo, o bairro Feu Rosa, porque estes poderiam “invadir” a área.

“(...) o condomínio nasce nessa ideia de proteger a área contra potenciais invasões. E aí se verificou a capacidade de se fazer um condomínio”. (...) "ele [o Boulevard] foi chamado de ecológico, porque todos os passos, desde o primeiro projeto, foram realizados dentro ou em conformidade com a legislação ambiental. Foi realizado com uma filosofia de conservação". (Entrevista realizada em 12/04/2012 com Biólogo, que trabalhou na liberação do loteamento na PMS)

Esse mesmo biólogo trabalhou na prefeitura, e, ao mesmo tempo, na elaboração, para os proprietários da fazenda, do projeto do loteamento, flagrante convergência da negociação de "facilidades" públicas criadas por agentes públicos ao serviço do setor privado.

Quanto à segurança, o loteamento é todo cercado por um muro de 3,30m de altura, vigiado por câmeras; a ele se sobrepõem $0,70 \mathrm{~m}$ de cerca elétrica. Há uma ronda interna feita por carro e moto. Esses veículos foram entregues pelo incorporador. A área da lagoa também é monitorada por câmeras; e na portaria há vidros blindados. Os empreendedores dizem 
promover um novo "conceito" de moradia, Residence e Resort, a exemplo da marca Alphaville:

\begin{abstract}
A natureza deslumbrante da Lagoa Jacuném ganha um projeto simplesmente magnífico: o Boulevard Lagoa Residence e Resort. Inédito na ideia e perfeito na concepção, o Boulevard Lagoa vem inovar a maneira de morar bem e de interpretar o conceito "qualidade de vida". Viver no Boulevard Lagoa é viver numa área de $900.000 \mathrm{~m}^{2}$ de muita paz, sofisticação, em uma superestrutura com inúmeras opções de esporte e lazer, além de um moderno sistema de segurança. Tudo isso ancorado por um cenário exuberante, repleto de verde e água, interligado por um sistema viário planejado, dotado de um Boulevard central encantador (Boulevard Lagoa. Residence \& Resort, s/d).
\end{abstract}

Esse mundo de "encantamento" é uma representação, um simulacro, que naturaliza processos sociais, a fim de recobrir o desrespeito às leis, justificar a apartação da cidade $\mathrm{e}$ vender um "estilo de vida" entre supostos iguais (MOURA, 2003): uma "qualidade de vida" à qual pouco importa, na propaganda, a vida real, a inserção no espaço e no território (Sobre os mitos e manipulações das propagandas desses empreendimentos, podem-se consultar ZANOTELLI et all, 2009; BRICALLI, 2010). No entanto, o loteamento não tem rede e estação de tratamento de esgoto próprio, como o obriga a legislação municipal. Seus novos residentes utilizam a rede de esgoto pública, o que vem causando problemas aos moradores do bairro Feu Rosa; a rede está sobrecarregada e eles têm de conviver com dejetos em suas ruas, uma vez que os dutos, não suportando tamanha vazão, estouram. Já questionaram a PMS e a concessionária responsável pelo tratamento do esgoto, a Companhia espírito-santense de Saneamento (Cesan) sobre o uso da Estação de Tratamento do bairro Feu Rosa pelo loteamento fechado, mais ainda não haviam obtido resposta. Assim, os moradores do bairro Feu Rosa convivem com a sobrecarga duma infraestrutura pública lançada por um empreendimento privado e ilegal. Há de se ressaltar que esta sobrecarga já existe num momento em que o loteamento fechado tem apenas 20 domicílios e 23 habitantes. Como ficará essa situação quando ele estiver completamente habitado?

O questionamento dos impactos desse loteamento na vida dos habitantes circunvizinhos não foi o primeiro. Nos primórdios da construção do Boulevard Lagoa, moradores do bairro Feu Rosa organizaram-se, chegando inclusive a atear fogo num trator, em protesto contra a obra e a consequente vedação do principal acesso à lagoa. Essas águas eram seu espaço de lazer, de cultura (muitas práticas religiosas ali se desenvolviam) e de subsistência (muitas pessoas dependiam da atividade pesqueira). Manifesta-se, desse modo, a fragmentação e a autossegregação como práticas que engendram efeitos espaciais 
e territoriais que vão além dos muros dos condomínios, chamando-nos a atenção para o fato de que é impossível viver inteiramente apartado em sociedade.

Sobre a fragmentação e segregação nas cidades, reportamos ao livro organizado de NavezBouchanine (2002), que nos dá a dimensão do debate teórico e empírico sobre essas questões no início dos anos 2000 e relativiza as percepções muito peremptórias sobre a fragmentação socioespacial. A Fragmentação nunca é absoluta: redes, contatos, conexões sempre existirão. Assim, para Lefebvre (2000), noutra perspectiva, o espaço da "modernidade" teria caráter preciso e tríplice: homogêneo, fragmentado e hierarquizado. Ele tenderia à homogeneização por diversas razões: elementos materiais, simbólicos, comunicacionais e homogeneizadores de espaços internos a conjuntos habitacionais etc. Mas, essas homogeneidades se fragmentam com os conjuntos e residências apartados e se complementam pela hierarquização dos espaços: residenciais, comerciais, de lazer, espaços destinados aos excluídos e aos incluídos etc. Essas constatações e interrogação nos permitem passar a analisar alguns dos aspectos dum condomínio fechado, plenamente habitado e responder a esta pergunta: como vivem os moradores dos condomínios?

\section{A VIDA COTIDIANA NO RESIDENCIAL MONTE VERDE}

O Residencial Monte Verde é um condomínio fechado, constituído de casas, sito no bairro Laranjeiras II, no Município de Serra. A área total do terreno é de 39ha e se divide em 9 etapas construídas separadamente. A primeira foi entregue no mês de outubro de 2007; a última ainda está em construção, com previsão para ser entregue em dezembro de 2012. 


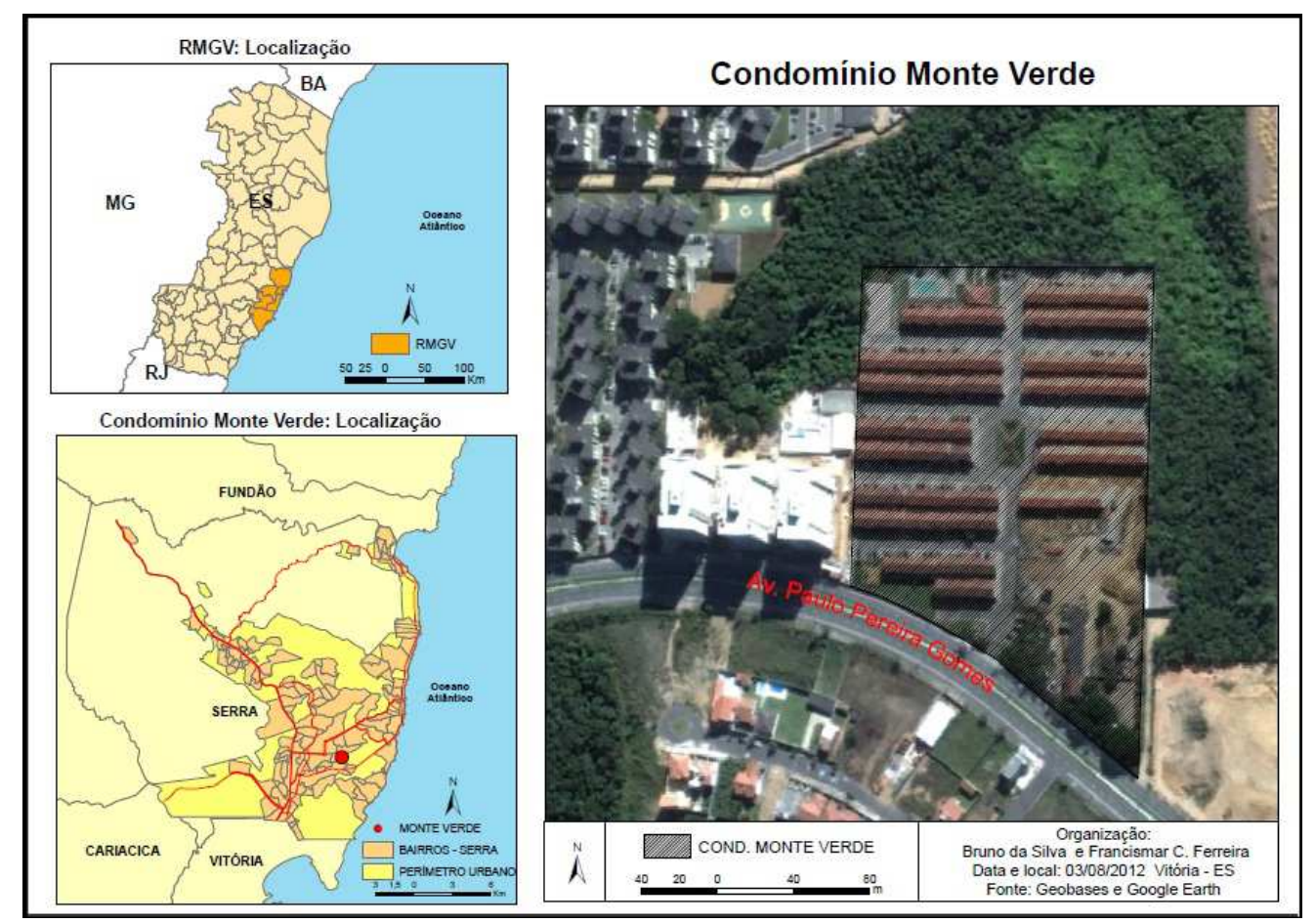

Figura 5: Localização do condomínio residencial Monte Verde.

O Residencial Monte Verde tem 223 casas duplex, com 69,20 $\mathrm{m}^{2}$, dentre as quais 153 possuem suíte. Cada unidade tem 3 quartos, sala, cozinha, 3 ou 2 banheiros, pequena área nos fundos das casas e 1 vaga de garagem, que fica na frente da casa e não possui cobertura. Para sistematizar os dados obtidos nas 5 entrevistas efetuadas e nos campos realizados no condomínio, separamos a análise da estrutura do condomínio e do seu "estilo de vida" por 5 temas: natureza, lazer, segurança, normas do condomínio e vizinhança, que passamos a detalhar.

\section{NATUREZA}

A natureza é frequentemente invocada pelos condomínios fechados em Serra, seja nas propagandas, nas logomarcas, seja no próprio nome do empreendimento. Isso pode ser interpretado tanto como estratégias mercadológicas utilizadas pelas empresas, a fim de se criar a ideia de que os condomínios fechados são espaços distantes do "caos" urbano e possuidores dum cotidiano repleto de paz, silêncio e tranquilidade (BRICALLI, 2010, ZANOTELLI et al., 2010) quanto como táticas de invocação das "raridades" do espaço produzidos para o consumo, como vimos para Alphaville.

Monte Verde se insere nesse contexto, uma vez que seu nome e sua logomarca apelam para os elementos da natureza. A palavra "Monte" traz a ideia de distância, separação em relação ao grupo maior; afastamento, elevação. "Verde" faz referência clara à ideia de 
floresta, vegetação. Sendo assim, "Monte Verde" seria um lugar ao mesmo tempo distante do grupo maior e repleto da paz que é propiciada pelos elementos da natureza.

Apesar de todo o anúncio sobre natureza, poucas árvores se veem dentro do condomínio. Nas ruas, aparecem apenas, em termos de natureza, jardins feitos pelos próprios moradores em frente às suas casas. Nas ruas dos fundos do condomínio, pequenas árvores crescem à beira da cerca; próximo ao salão de festas, elas também aparecem bem tímidas. Na praça ao centro do condomínio, também existem algumas, mas todas ainda em crescimento.

O que se percebe nas entrevistas, contudo, é que o verde que mais faz diferença no condomínio, na verdade, não pertence a ele, mas à reserva que o cerca de dois lados. Alguns moradores citaram sua relevância em termos de tranquilidade e segurança. Em alguns casos, inclusive, essa reserva foi decisiva para a escolha da casa, uma vez que o morador queria ficar próximo a ela. $\mathrm{O}$ fato de a maior sensação de natureza no condomínio ser provocada pela reserva revela a ironia dum empreendimento privado ter seu nome e sua logomarca justificados por um elemento que é público. Reitera-se aqui a confusão entre o público e o privado, vista precedentemente, indicando a necessidade de irmos para além da partilha público-privado como razão de todas as coisas. Antes dessa partilha nas sociedades ditas pré-estatais ou nas sociedades indígenas, em geral, contemporâneas nossas, há o coletivo, aquilo que é partilhado e de uso comum, sobretudo as terras, a natureza, cujas relações simbólicas e de cooperação se estabelecem entre os atores. Isso nos adverte que não necessariamente tenhamos que reivindicar o público, sem, evidentemente, denegá-lo, pois muitas vezes ele está contaminado dessas relações de poderes e de ambiguidades que não sustentam o interesse coletivo (ver a esse propósito desse debate DELEUZE-GUATTARI, 1980; MUMFORD, 1961; SOJA, 2008).

\section{LAZER}

O condomínio possui os seguintes itens de lazer: piscina, quadra de esportes, salão de festas, um pequeno parquinho para as crianças e uma churrasqueira. A piscina, a quadra e a churrasqueira são pouco usadas pelos moradores. Na maioria das vezes, esses equipamentos são mais requisitados nos finais de semana. $\mathrm{O}$ problema é que existe 1 churrasqueira para 223 casas, e ela está localizada ao lado da piscina. O morador que a reservar, acaba tomando posse da piscina naquele momento. Acontece da seguinte forma: no Regimento Interno, consta uma norma que diz que a reserva da churrasqueira não inclui reserva da piscina, porém a maioria das festas realizadas no condomínio é feita por um 
morador que convida seus familiares e amigos que, por sua vez, não moram no condomínio. Desta forma, devido à proximidade, a piscina acaba sendo usada pelas pessoas que estão na churrasqueira. Muitos moradores, sentindo-se intimidados pela presença dos visitantes, acabam não usando a piscina.

O salão de festas é um item que é utilizado, algumas vezes, para a realização de festas dos moradores (cabe ressaltar que a maioria das festas não é feita entre moradores). Entretanto, isso não ocorre com todo o condomínio. Existe uma organização das pessoas por rua e, às vezes, uma rua ou outra resolve organizar uma festa. Assim, encontramos, muitas vezes, organizações mais ou menos espontâneas que recriam a vida de bairro, mesmo que em condições particulares e submetidos a um controle dos vizinhos, mas, até que ponto, esse mecanismo não seria semelhante às relações de vizinhança em bairros clássicos? Sobre a vizinhança, retornaremos mais adiante.

\section{SEGURANÇA}

A segurança ou, a sensação duma pretensa segurança, é propiciada pelo fechamento do espaço e, é importante acrescentar, pela certeza de que todas as coisas estão sendo vistas por algum tipo de olhar. Seja ele provindo de câmeras, seja de vizinhos etc. Os muros e as câmeras "protegem", mas também servem para controlar os que vivem nesses conjuntos. A velha prática dos muros como forma de controle sobre os habitantes existe desde os primórdios das cidades, como nos demonstra Mumford (2008 [1961]).

Os principais itens de segurança do Condomínio Residencial Monte Verde são muros, cercas, câmeras, portaria guardada por um funcionário e adesivos identificadores nos carros dos moradores. Percebe-se, assim, que os itens se dividem em duas categorias: uma que separa os condôminos daqueles que estão do lado de fora e uma que permite a visibilidade e a identificação dos que estão no interior dos muros ou que ali pretendem adentrar. Toda a divisa entre o condomínio e a reserva natural é feita pela cerca descrita no parágrafo anterior. Cabe ressaltar que ela é feita dum material bastante frágil e, claramente, não possui um alto potencial de isolamento, pois pode facilmente ser transpassada.

A justificativa dada por um morador para o fato de a cerca substituir o muro nos pontos em que a reserva toca o empreendimento foi a de que ela permite a visibilidade de qualquer movimento estranho que possa vir a ocorrer do outro lado. É um ponto de vista bastante contestável, uma vez que noutras partes, onde há muro, não se vê essa mesma preocupação em ver o que há por detrás. O que parece ser, de fato, a motivação da cerca, é que ela foi a

Geo UERJ - Ano $14, n^{\circ} .23$, v. 2, $2^{\circ}$ semestre de 2012 p. 619-655

ISSN: 1415-7543 E-ISSN: 1981-9021

http://www.e-publicacoes.uerj.br/index.php/geouerj 
forma encontrada pelo empreendimento para se apropriar da reserva natural e fazê-la ser quase parte do próprio condomínio. É possível ver as árvores de frente, desde a base; sente-se o cheiro e ouve-se o som do vento tocando as folhas. A reserva é o símbolo duma natureza que estaria escassa nos dias atuais; uma raridade e, por isso, importantíssima para os felizardos que ali habitam.

A ineficácia da cerca em termos de segurança não passa despercebida. Os moradores deixam pistas de que não confiam inteiramente nela, mas, ao mesmo tempo, por razões que não é possível explicar, eles transferem a sensação de segurança para a reserva. Ela seria a grande isolante do condomínio, ao passo que a cerca seria mero detalhe.

Quatro das cinco famílias entrevistadas moravam em casas comuns antes de se mudarem para o condomínio. Todas, apesar de já terem tido a experiência, afirmam que não se veem mais morando fora dum condomínio fechado, pois a insegurança urbana está muito grande. Uma das pessoas entrevistadas disse, inclusive, que não tem mais coragem de dormir na casa de sua mãe, uma vez que a casa é na rua. Essa mesma pessoa mora há menos de 1 ano no condomínio. Inicialmente, o que se percebe é que o condomínio foi adquirido principalmente por causa do preço relativamente baixo das casas, incluindo aí a facilidade de pagamento ${ }^{7}$. Entretanto, um medo da cidade começa a crescer nos residentes a partir do momento em que começam a morar entre os muros. A crença na necessidade constante de se aprimorarem os equipamentos de segurança, associada ao conteúdo das matérias jornalísticas locais, gera uma desconfiança das ruas e das pessoas a tal ponto que, aos poucos, os encontros e as surpresas vão se reduzindo, as ruas se esvaziando e a cidade mudando de função. Constrói-se, dessa maneira, o medo do Outro, do desconhecido, um medo construído socialmente. Não podemos negligenciar no aspecto relativo à segurança os fatos de uma criminalidade real bem significativa que toca, sobretudo, no que diz respeito aos homicídios, na RMGV os mais pobres e vivendo nas periferias das cidades , e, por outro lado, a criminalidade relativa ao patrimônio que atinge todas as camadas sociais e, em particular, os centros comerciais e os bairros onde a riqueza é mais concentrada (Cf. ZANOTELLI et al; 2011). Assim, sobre uma base real, muitas comunidades fechadas se constituem como forma de confrontar um perigo que veem como eminente, tentando substituir o Estado no seu papel de propiciar segurança ao conjunto da sociedade. Sobre esse aspecto e as iniciativas tomadas por comunidades de bairros, por comunidades

\footnotetext{
${ }^{7}$ Os moradores que adquiriram o imóvel na planta, em meados dos anos 2000, pagaram R $\$ 75.000,00$ pela residência. Hoje o imóvel é negociado pelo dobro do preço ou por valor superior.

Geo UERJ - Ano 14, no. 23, v. 2, $2^{\circ}$ semestre de 2012 p. 619-655

ISSN: 1415-7543 E-ISSN: 1981-9021

http://www.e-publicacoes.uerj.br/index.php/geouerj
} 
fechadas e outros conjuntos de moradores nos Estados Unidos que são, também, a demonstração de uma reação dos habitantes à inércia da potência pública pode se consultar o capítulo 10 do livro Posmetrópole de Soja (Op. cit. p.419 a 450).

\section{NORMAS DO CONDOMÍNIO}

O Regimento Interno é o documento mais importante, em termos normativos, do Condomínio Residencial Monte Verde, uma vez que é nele que consta um panorama geral de todas as regras de utilização dos espaços, bem como de convivência entre os moradores. Ele é resultado da aplicação do artigo 9 da Lei federal 4.591/64 (BRASIL, 1964), que diz:

\footnotetext{
Os proprietários, promitentes compradores, cessionários ou promitentes cessionários dos direitos pertinentes à aquisição de unidades autônomas, em edificações a serem construídas, em construção ou já construídas, elaborarão, por escrito, a Convenção de condomínio, e deverão, também, por contrato ou por deliberação em assembleia, aprovar o Regimento Interno da edificação ou conjunto de edificações (Lei 4.591/64).
}

Fizemos uma análise desse material, a fim de delinearmos que tipo de comportamento ou que tipo de sujeito esse documento (ou quem o elaborara) almeja abrigar no interior dos muros do empreendimento. O Regimento Interno do Condomínio Residencial Monte Verde tem 14 páginas; foi elaborado em 2008, estando em vigor desde então até a presente data. Ele foi assinado pelo síndico e pelo presidente do Conselho Consultivo, que é um grupo eleito pelos moradores e tem por finalidade auxiliar o síndico no exercício de sua administração, em 21 de maio de 2008. Está organizado em 36 artigos que se distribuem em tópicos, cujo tema engloba parte da natureza do que se deseja reger. Os temas, em termos gerais, são: obrigação de cumprimento do regimento; regras gerais de utilização da unidade autônoma, áreas comuns e animais de estimação; direitos, deveres e obrigações dos condôminos; portaria e recepção; zeladoria; quadra de esportes; churrasqueira; estacionamento; limpeza; mudanças e transporte; despesas comuns; fundo de reserva; seguro, incêndio e reconstrução obrigatória; livros; penalidades e ações judiciais; restrições de reformas e construções; disposições gerais. Nota-se que se trata dum documento que procura englobar o máximo de aspectos da vida cotidiana, sobre os quais fixa normas, define os instrumentos a serem utilizados, visando ao cumprimento, bem como às penalidades aos infratores. É importante ressaltar que sempre se busca extrair algo útil no exercício da pena. Por exemplo, as multas, segundo o documento, serão destinadas ao fundo de reserva do condomínio. 
Cada morador, ocupante, empregado e visitante está obrigado a seguir às normas do regimento, não lhes cabendo o direito de invocar um eventual desconhecimento de seu conteúdo. Mesmo nos casos de casas alugadas, nos contratos de aluguel deve constar uma cláusula que o locatário e todos os seus dependentes, visitantes, empregados etc., se comprometem a respeitar as normas presentes no Regimento Interno.

Para que se tenha o mínimo possível de infrações, o regimento cita a existência do livro de ocorrências: caderno que fica na portaria e tem por função registrar críticas, sugestões, bem como reclamações dos moradores sobre as infrações alheias. As ocorrências devem ser identificadas e, a partir daí, o síndico analisará individualmente cada caso, a fim de se tomarem as medidas cabíveis. O documento afirma ainda a legitimidade de se recorrer diretamente ao síndico quando da desobediência de outrem às regras condominiais.

Numa análise sobre as ocorrências em livro de Ata e sobre as normas do condomínio de casas de Aldeia de Laranjeiras (o mais antigo condomínio com casas de classe média de Serra, inaugurado em 2004) bem como por meio de entrevistas, constatamos serem inúmeros os conflitos dentro do condomínio (ZANOTELLI et al., 2010). Os desentendimentos ocorrem pelos mais variados motivos: problemas com cachorro, excesso de velocidade de carros pelas ruas do condomínio e vizinhos que fazem muito barulho durante a noite. Os casos menos recorrentes, mas ainda assim presentes entre as ocorrências registradas são os pequenos furtos e arrombamentos de casas; a intolerância com as diferenças dos outros; e as delações anônimas. Ocorreram alguns casos de conflitos em relação aos espaços comuns, por exemplo, de moradores que utilizaram a área de festas e, depois, alguns equipamentos desaparecem. Outro problema constatado foi que alguns moradores se apropriaram duma parte da área comum, localizada no centro do condomínio, construindo muro em torno duma área que deveria ser um bosque, de acordo com a planta original, portanto, uma área de uso coletivo. O que de fato se observa a respeito das relações entre os moradores é certa afinidade estabelecida entre alguns, mas, por outro lado, de maneira geral, há conflitos recorrentes que remetem mesmo à reprodução de valores individualistas presentes na sociedade contemporânea que, em nenhum momento se desliga do condomínio fechado. Isso, de certa maneira, se explicita com nuances em Monte Verde.

Em termos gerais, as regras do condomínio Monte Verde consistem em não perturbar a paz, com músicas ou qualquer tipo de ruído em níveis elevados; não colocar em risco a vida de crianças, seja com animais de estimação perigosos, seja excedendo o limite de Geo UERJ - Ano 14, $n^{\circ} .23$, v. 2, $2^{\circ}$ semestre de 2012 p. 619-655 
velocidade dos carros; zelar pela limpeza do condomínio; manter a padronização da arquitetura das casas; elaborar festas apenas com agendamento prévio, com lista de convidados e previsão de início e término; manter-se em dia com as despesas do condomínio; andar de bicicletas e patins apenas nas ruas, sendo proibido o uso desses objetos nas calçadas; e não se utilizar de palavrões ou xingamentos dentro do condomínio. Sobre o último item, é importante considerar que o documento afirma o seguinte:

\begin{abstract}
O condômino que por seu reiterado comportamento antissocial, gerar incompatibilidade de convivência com os demais condôminos ou possuidores, poderá ser constrangido a pagar multa correspondente ao décuplo do valor atribuído à contribuição para as despesas condominiais, até ulterior deliberação da assembleia. Entende-se por comportamento antissocial, o desrespeito às normas do Regimento Interno, que visam ao bom convívio em condomínio, bem como, utilizar-se de palavras obscenas, xingamentos, ofensas pessoais e morais a outros cidadãos, condôminos e funcionários do condomínio, quebra de objetos ou bens do condomínio, enfim, atentar contra a moral e os bons costumes (REGIMENTO INTERNO DO CONDOMÍNIO MONTE VERDE, 2008, p. 11).
\end{abstract}

É demasiado vaga a noção que serve de parâmetro para definir as regras sobre as quais versa essa citação. A moral e os bons costumes estão aí naturalizados e destituídos de história. Qual moral? Que costumes? De que modo de vida o documento se está utilizando, para reger os relacionamentos? Parece aí que se atenta para a manutenção de certo tipo de comportamento. Isso será mais bem discutido adiante.

Percebe-se que, para funcionar, as normas se utilizam de certos instrumentos principais: o livro de ocorrência, as reuniões condominiais e o olhar, uma vez que pela visibilidade de todas as coisas as regras circularão entre as pessoas. O Regimento Interno não só impõe sobre os indivíduos o dever de seguir as normas, mas, também, os investem do poder de exercê-las, uma vez que se responsabilizarão pela denúncia das infrações dos que não se adequarem às obrigações do condomínio. Isso torna o outro não só o amigo potencial, mas, também, o olho daquele que vigia (FOUCAULT, 1975). Em alguns casos, pessoas fogem aos relacionamentos; noutros, os relacionamentos são mais fortes, então as pessoas fogem às regras. Conforme veremos a seguir, os condôminos costumam se organizar de acordo com as ruas onde moram. Numa delas, verificou-se um fato demasiado interessante: uma relação de amizade muito forte se estabeleceu entre os moradores. Realizam festas entre si; almoços comunitários; ficam até tarde da noite na rua conversando e bebendo e até combinam passeios. Acontece que esses moradores, por motivos distintos, se desligaram da normatização convencional do condomínio: não participam das reuniões e, quando precisam resolver algum problema (inerente àquela rua), realizam reuniões entre si para decidir como proceder.

Geo UERJ - Ano $14, n^{\circ} .23$, v. 2, $2^{\circ}$ semestre de 2012 p. 619-655

ISSN: 1415-7543 E-ISSN: 1981-9021

http://www.e-publicacoes.uerj.br/index.php/geouerj 
Evidentemente, esses moradores têm de seguir as regras do condomínio, entretanto, no que concerne fazer funcionar a lógica do poder condominial da forma como está escrito no Regimento Interno, eles têm trocado um pouco as funções, definindo outros pontos de apoio e outras estratégias de luta. Segundo Foucault (1981), o poder circula entre os sujeitos; produz os indivíduos; e estes se tornam centros de transmissão desse mesmo poder. No momento em que eles têm feito corpo com o poder, têm dado a ele outra direção; não mais aquela prevista pelos mecanismos que o delimitava, mas a que um jogo de interesses permitiu que fosse dada. Cabe ressaltar, contudo, que ainda se trata do poder. Mesmo que com outra característica e exercido a partir de outros sujeitos, ele apresenta a mesma essência: trata-se dum exercício que perpassa os indivíduos e compõe as subjetividades, produzindo padrões de comportamento e ideais de sujeitos.

Isso se percebe no fato de nessa mesma rua ter ocorrido um caso dum morador que, à exceção dos demais, não se tem adaptado aos relacionamentos, uma vez que apresenta um padrão de comportamento profundamente desconectado daquilo que se considera ideal. Nas entrevistas, apareceram denúncias sobre o fato de ele ter praticado "atentado contra o pudor", realizado agressões, perturbado a paz e usado drogas, porém nada disso foi informado à administração convencional do condomínio. Tudo foi resolvido a partir das reuniões que eles próprios realizaram. Até mesmo a polícia chegou a ser solicitada numa determinada situação envolvendo esse sujeito tido como indesejado.

De todos os 5 entrevistados, apenas 1 frequenta as reuniões de condomínio, entretanto, o caso da rua supracitada (reuniões entre si), não apareceu outra vez dentro do universo pesquisado. $\mathrm{O}$ fato de poucas pessoas participarem implica uma concentração do poder de decisão nas mãos de poucas pessoas que nos pareceu serem sempre as mesmas.

\section{VIZINHANÇA}

Cada quarteirão do condomínio é composto por conjuntos de blocos e cada bloco possui 8 casas. As ruas são compostas por 6 blocos, sendo 3 de cada lado, havendo exceções. $O$ croqui da Figura 6 mostra de que forma as casas estão distribuídas dentro de cada bloco.

As residências têm paredes geminadas, sendo que aquelas localizadas nas extremidades do bloco apresentam apenas duas; as demais convivem com 3 paredes. Segundo um dos moradores entrevistados, a intenção da empresa ao decidir por elaborar casas nesse padrão se deu pelo fato de que assim ela dispensaria menos recursos, economizando na produção $\mathrm{e}$, consequentemente, obtendo maiores lucros.

Geo UERJ - Ano 14, no ${ }^{\circ} .23$, v. 2, $2^{\circ}$ semestre de 2012 p. 619-655

ISSN: 1415-7543 E-ISSN: 1981-9021

http://www.e-publicacoes.uerj.br/index.php/geouerj 
Acontece que, para além da economia obtida pela empresa construtora, as paredes geminadas geram uma espécie de desconforto nos moradores que, perante a fragilidade do material que permite a passagem de sons de todos os tipos, reclamam da falta de privacidade decorrente desse padrão arquitetônico. O espaço, nesse sentido, acaba, mesmo não tendo sido construído com essa finalidade, potencializando a lógica do poder no condomínio, que têm na transparência seu suporte fundamental. As pessoas ouvem os vizinhos, portanto sabem que serão ouvidas também, como diz um morador entrevistado: "Um barulho lá na última casa, a gente ouve aqui como se estivesse dentro da nossa".

Além da falta de privacidade fornecida pela circulação dos sons, a separação das pequenas áreas atrás das casas, permite que muita coisa seja visível e estudada pelos vizinhos. Um panóptico contemporâneo? Trata-se dum lugar que permite a todos serem vistos ou faz crer que podem ser vistos, como nos indica a estrutura do panóptico inventado no século XVIII para as prisões por Bentham e que, segundo Foucault, será o paradigma da sociedade disciplinar fundada na inculcação do sentimento de ser vigiado, mesmo quando, aparentemente, ninguém nos vigia, mecanismo que é replicado em todas as esferas da vida social, fundado na forma espacial das instituições (FOUCAULT, 1976)? Ou ainda um mecanismo do tipo sociedade do controle em que, tornando-se invisíveis, os sistemas de controle funcionam de maneira integrada e automática, com as câmeras atuando permanentemente e permitindo a qualquer momento se extraírem informações das bases de dados constituídas?

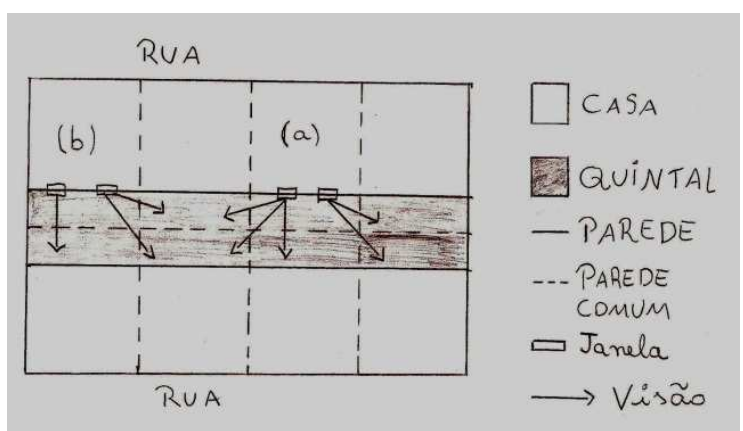

Figura 6: Croqui representando a vista vertical das possibilidades de visão dos quintais vizinhos a partir das janelas dos pavimentos superiores.

Percebe-se, pela da análise dessa representação (Fig. 6), que as casas localizadas nas extremidades, indicadas por "b", enxergam 3 quintais e são vistas também por 3 vizinhos. Ao passo que as residências interiores ao bloco, assinaladas por "a", enxergam 5 quintais e são vistas também por 5 vizinhos. Resumindo, as casas das extremidades possuem certa 
privacidade em relação às outras, uma vez que, além de serem vistas por menos vizinhos, possuem menos paredes geminadas.

As pessoas se veem e se ouvem ao mesmo tempo em que a regra é imposta por aqueles que enxergam o que há de "errado". A arquitetura desse espaço, conforme se viu, permite uma circulação do poder que tem no outro sua justificativa, uma vez que é ele quem poderá fazer recair sobre cada um a punição. Em muitos casos, foi percebida a vontade de se reduzir o universo de relações pessoais, a fim de se guardar certa privacidade. Entretanto, conforme já foi dito, as pessoas costumam organizar-se por ruas. Assim, em cada caso a situação ocorre de forma particular.

Em determinada rua, as pessoas não costumam se relacionar, uma vez que, segundo informações obtidas, a maioria dos moradores mudou-se recentemente. Noutra rua, por sua vez, há certa amizade entre os moradores, mas nada muito concreto nem organizado ao ponto de serem elaboradas festas comuns. O maior exemplo de relacionamento entre os moradores, de fato, foi constatado na rua que chamaremos de A, da qual já se falou anteriormente. Certa rua ao Norte da rua A, segundo informações, também apresenta uma boa relação entre os moradores. No momento da visita ao empreendimento, havia 7 famílias dessa rua organizando uma viagem para um resort.

As relações de vizinhança são, portanto, complexas. Os que buscam "proteção" em relação aos de fora do condomínio, encontram-se submetidos a controles cruzados da vizinhança e dos responsáveis pela administração condominial, no entanto cooperações e relações se estabelecem entre os habitantes, diferentes comportamentos afloram e podem, em certas ocasiões, se semelhar àqueles dum bairro clássico, lembrando-nos, aqui, de maneira incipiente, a tentativa de recriação duma vida de bairro, contra aquilo que se poderia esperar de um condomínio fechado.

\section{CONSIDERAÇÕES FINAIS}

A inserção social e espacial dos diferentes condomínios analisados, malgrado sua diferença de localização, de tamanho, de estrutura, de equipamentos, de valores e de habitantes presentes e futuros, revelam-nos essencialmente cinco características: as relações ambíguas e interessadas entre o setor privado e o setor público responsável pelo disciplinamento do uso do solo e pela proteção das paisagens e do patrimônio; a transformação do Meio Ambiente em moeda de troca, ocupando e valorizando os sítios com as melhores paisagens, que são ambientalmente os mais ricos e mais frágeis; a privatização do que é 
coletivo (a natureza, as florestas, as águas etc.) e do que deveria ser público (ruas, praças, parques etc); a reafirmação da segregação e da autossegregação num espaço onde todo enclave traz efeitos diretos e indiretos previsíveis e imprevisíveis tanto internamente como externamente aos condomínios estudados, a exemplo das vidas vigiadas e das resistências a esse mecanismo em Monte Verde e noutros lugares, além do impacto gerado sobre o meio de vida e sobre a rede pública de esgoto que já atendia a um bairro popular, o que gerou reações de sua população em relação ao Boulevard Lagoa; por último, e não menos importante, a reafirmação da in-segurança como leitmotiv justificador e alienador dos "bairros" apartados, tendo ou não como base uma realidade empírica.

O que se percebe, em particular no condomínio Monte Verde, é que o "viver em comunidade" é no mínimo problemático (isso também se nota em Aldeia de Laranjeiras), mas esse "viver" não se reduz às visões maniqueístas que poderíamos ter daqueles que habitam esses espaços. Zonas de resistência, de desacordos e de solidariedade emergem nos condomínios analisados, bem como relações conflituosas, ou não, com a vizinhança, demonstrando que os homens refazem laços de sociabilidade em todas as condições sociais, mesmo naquelas o mais adversas possível. Assim, o que se pode provisoriamente concluir acerca dos relacionamentos entre vizinhos, a partir do observado, é que é impossível realizar uma generalização sobre o conteúdo das relações sociais em condomínios fechados. As pessoas são diferentes e se organizam a partir de lógicas difíceis demais de se preverem. Nesse sentido, cada caso carece duma observação específica, para que se produzam materiais concretos. $O$ que se pode afirmar é que a lógica de funcionamento das regras e da segurança acaba permitindo certo padrão de contato ou de aproximação entre as pessoas, uma vez que existe um exercício de poder que medeia a relação entre elas. Entretanto, esse exercício pode ser modificado, readaptado, moldado segundo interesses diversos que se difundem nesses espaços.

Duas lógicas estruturantes são transversais aos espaços estudados. A primeira lógica é a mercantil. Ela se funda, igualmente, nas distinções sociais e nas lógicas de classes, reafirmando os preconceitos presentes na sociedade brasileira - que usa todos os meios do marketing para vender uma ilusão de comunidade ou de vida tranquila e apaziguada. Tratase do velho sonho suburbano da América do Norte e da Cidade Jardim, sonho esse desnaturado reavivado ente nós (ver, a esse propósito, SOJA, 2008[2000]), com o objetivo de se retirar o máximo de renda e lucro dos empreendimentos, desrespeitando a geografia humana e física e reafirmando os preceitos de segregação, tão nocivos em nossa sociedade, 
ao ponto que eles retornam como um efeito em bumerangue sobre o conjunto da sociedade, aumentando aquilo que se pretendia evitar, o individualismo e a violência social e simbólica (ZANOTELLI, 2011). A segunda lógica estrutural é aquela da vida em sociedade relativamente fechada que revela que, apesar dos projetos o mais desvairados possível e dos interesses os mais contraditórios possíveis, o homem resta uma matéria viva, que reage, luta, cria, diferencia-se e nunca se adapta inteiramente a nenhuma estrutura rígida, apesar de ser permanentemente trabalhado pelas determinações indeterminadas das estruturas de dominação social tanto simbólicas como materiais (BOURDIEU, 1980).

Assim, estaríamos diante duma sociedade do controle indeterminado, normalizado e aceito como tal, por meio da penetração em nossas vidas de tecnologias e formas arquiteturais de enclausuramento naturalizadas e normalizadas, mas que não se impõem sem contradições, retornos não esperados, conflitos e resistências.

Portanto, os conjuntos de condomínios seriam a cristalização provisória de relações de poder, estrutura aparente feito verdade incorporada e vivenciada como "normal", sem culpa e meias palavras, pelos habitantes/consumidores, para além duma hipotética consciência de cidadania ou exemplaridade do "espaço público" que poderia fazer face à sua proliferação. Donde a dificuldade do embate socioespacial para se reverterem as escolhas das prefeituras, dos agentes imobiliários e dos cidadãos na produção de tais conjuntos de hábitat no caso do Município de Serra na RMGV.

\section{REFERÊNCIAS}

BOULEVARD LAGOA. Residence \& Resort. Material de propaganda, s/d.

BOURDIEU, Pierre. Le sens pratique. Paris: Minuit, 1980.

BRASIL. Lei 4.591/64, de 16 de dezembro de 1964. Disponível em http://www.planalto.gov.br/ccivil 03/leis/14591.htm. Acesso em: 20 jul. 2011. . Lei $\mathrm{N}^{\circ} 6.766$ de 19 de Dezembro de 1979. Disponível em: http://www.planalto.gov.br/ccivil 03/leis/l6766.htm. Acesso em: 14 de jun. 2011.

.Portaria 07 de 1998 do IPHAN, de 01 de dezembro de 1988. Disponível em: http://portal.iphan.gov.br/portal/baixaFcdAnexo.do?id=319. Acesso em: 14 maio. 2011.

.Lei federal $\mathrm{N}^{\mathrm{o}}$ 3.924, de 26 de julho de 1961. Disponível em: <http://www.planalto.gov.br/ccivil_03/leis/1950-1969/L3924.htm>. Acesso em: 14 maio. 2012.

BRICALLI, Iafet Leonardi. O mito da natureza nas propagandas dos condomínios e loteamentos fechados do Município de Serra (ES). 2010. 122 f. Monografia (Monografia em Geografia) - Departamento de Geografia, Universidade Federal do Espírito Santo, Vitória, 2010. 
CALDEIRA, Tereza Pires do Rio. Cidade de muros: crime, segregação e cidadania em São Paulo. São Paulo: 34/Edusp, 2000.

CENTRO DE ESTUDOS AMBIENTAIS (Brasil). Cristal Empreendimentos Imobiliários. Diagnóstico ambiental estudo básico: Parque da Lagoa- condomínio Ecológico. Serra (ES), 1995.

CENTRO DE ESTUDOS AMBIENTAIS (Brasil). Cristal Empreendimentos Imobiliários Ltda. Condicionantes relativas à Licença de instalação do Parque da Lagoa: condomínio ecológico. Serra (ES), 2002.

CUNHA, Ernesto Salles. Patologia odontomaxilar das populações de sambaquis. Revista Brasileira de Odontologia, Rio de Janeiro, vol. 17, p.348-370, novembro/dezembro 1959(?).

DELEUZE, Gilles. Foucault. São Paulo: Brasiliense, 2005.

Pourparlers. 1972-1990. Paris: Minuit, 2003 [1990].

Capitalisme et schizophrénie 2: mille plateaux. Paris: Minuit, 1980.

ESPÍRITO SANTO (Estado). Lei 7.943/2004 Disponível em http://www.meioambiente.es.gov.br/default.asp. Acesso em 23 de outubro de 2012.

FOUCAULT, M. Vigiar e punir: nascimento da prisão. Petrópolis: Vozes, 1991.

Microfísica do poder. Rio de Janeiro: Graal, 1979.

História da sexualidade I: a vontade de saber. São Paulo: Graal, 1988.

FOUCAULT, Michel; MACHADO, Roberto. Microfísica do poder. São Paulo: Graal, 1979.

GAZETA on line, 29 set. 2012. Disponível em http://gazetaonline.globo.com/

GRAHAM, Stephn. Villes sous contrôle : la militarisation de l'espace urbain. Paris: La Découverte, 2012. [Edição inglesa: Cities Under Siege: the New Military Urbanism. Londres; New York: Verso, 2010].

HARVEY. David. O enigma do capital e as crises do capitalismo. São Paulo: Boitempo, 2011.

INSTITUTO BRASILEIRO DE GEOGRAFIA E ESTATÍSTICA, Censo de 2010. Rio de Janeiro: IBGE, 2010

LEFEBVRE, Henri. La production de l'espace. Paris: Anthropos, 2000.

MARICATO, Ermínia. O impasse da política urbana no Brasil. São Paulo: Vozes, 2011.

MARX, Karl. O Capital: o processo global da produção capitalista. Tomo 2 (Parte Segunda). Tradução Regis Barbosa e Flávio R. Kothe. São Paulo: Nova Cultura, 1988. Vol. V. Livro Terceiro.

MOURA, C. P. Vivendo entre muros: O sonho da aldeia. In: Pesquisas urbanas: desafios do trabalho antropológico. K. Kuschinir e G. Velho (Org.). Rio de Janeiro: Zahar, 2003.

MUMFORD, Lewis. A cidade na história: suas origens, transformações e perspectivas. São Paulo: Martins Fontes, 2008 [1961].

NAVEZ-BOUCHANINE, Françoise (Org.). La fragmentation en question : des villes entre fragmentation spatiale et fragmentation sociale ? Paris : L'Harmattan, 2002. 
PEROTA, Celso. Traficantes de técnicas" ou construtores de modelos: trajetória e a visão de um arqueólogo que iniciou sua formação no CEPA. In: Anais do seminário trajetórias e perspectivas da arqueologia brasileira. Universidade Federal do Paraná, 2007.

SERRA. Lei $N^{\circ}$. 3.592, de 01 de julho de 2010. Disponível em: $<$ http://legis.serra.es.gov.br/normas/images/leis/html/L35922010.html>. Acesso em: 14 maio. 2012.

Lei $\mathrm{N}^{\mathrm{o}} 2.135$, de 25 de novembro de 1998. Disponível em: <http://legis.serra.es.gov.br/normas/. Acesso em: 10 de jun. 2012.

Lei $\mathrm{N}^{\mathrm{o}}$ 3201, de 14 de fevereiro de 2008. Disponível em: http://legis.serra.es.gov.br/normas/images/leis/html/L32012008.html. Acesso em: 10 de jun. 2012.

Decreto municipal $\mathrm{n}^{\mathrm{o}} 3.286$ de 11 de setembro de 2006. Disponível em: < http://legis.serra.es.gov.br/normas/>. Acesso em: 19 de jul. 2011.

.AGENDA SERRA 21. Plano estratégico da cidade 2007-2027. Prefeitura Municipal de Serra, 2008.

.PLANO diretor municipal de Serra - ES Disponível em: <http://legis.serra.es.gov.br/normas/images/leis/html/L38202012.html>. Acesso em: 12 mar. 2012.

REGIMENTO Interno do Condomínio Residencial Monte Verde. Serra-ES, 2008.

RIBEIRO, Rosimery Aliprandi. Formação socioespacial da antiga vila operária de Chico City, Região Metropolitana da Grande Vitória, Espírito Santo. 2011. 170f. Dissertação (Mestrado em Geografia), Programa de Pós-Graduação em Geografia, Universidade Federal do Espírito Santo, 2011.

SANTOS, R.C.B.: Alphaville e Tamboré: circunstâncias históricas medievais na apropriação de terras para condomínio de alto padrão na Grande São Paulo. 2003; Simpósio; Mesa de Comunicação Coordenada "Reconstituindo a Evolução Histórica de Lugares Urbanos", Universidade Federal de Pernambuco; Português; Recife; Brasil; Vários; 10 a 14 nov. 2003.

SOJA Edward W. Postmetropolis. Estudios críticos sobre las ciudades y las regiones. Madrid: Traficantes de Sueños, 2008, Tradução de Verónica Hendel y Mónica Cifuentes [Versão original em inglês: Postmetropolis: critical studies of cities and regions, Los Ángeles: Blackwell Publishing, 2000].

SOUZA, M. L. Fobópole: O medo generalizado e a militarização da questão urbana. Rio de Janeiro. Bertrand Brasil, 2008.

SOUZA, M. L. O desafio metropolitano: um estudo sobre a problemática sócio-espacial nas metrópoles brasileiras. Rio de Janeiro: Bertrand Brasil, 1999.

ZANOTELLI, C. L.. Entre sociedade disciplinares e sociedade de controle: interrogações sobre o hábitat enclausurado na cidade. In: IX Encontro nacional da associação de pósgraduação e pesquisa em geografia (IX Ananpege). Goiânia, 2011.

ZANOTELLI, C. L, Et al. Espaços fechados. Estudo de caso de condomínios e loteamentos fechados do município de Serra (ES). (Aceito e a ser apresentado no XVI encontro de geógrafos do Brasil). Porto Alegre, RS, 2010.

A busca do paraíso perdido das comunidades autossegregadas no Município de Serra (Estado do Espírito Santo) - Brasil. Anais do XII Encontro dos Geógrafos da América Latina. Montevidéu, Uruguai, 2009.

\author{
Geo UERJ - Ano 14, no. 23, v. 2, $2^{\circ}$ semestre de 2012 p. 619-655 \\ ISSN: 1415-7543 E-ISSN: 1981-9021 \\ http://www.e-publicacoes.uerj.br/index.php/geouerj
}


Atlas da criminalidade no Espírito Santo. São Paulo: Annablume; Espírito Santo: Fapes, 2011.

ZANOTELLI, C. L.; FERREIRA, F. C. A disseminação dos condomínios fechados em Serra - Região Metropolitana da Grande Vitória, ES - e os impactos ambientais da implantação de Alphaville. In: XII Simpósio Nacional de Geografia Urbana (XII Simpurb). Belo Horizonte, 2011.

Alphaville e sambaquis: o caso de Serra (ES). In: XVII Encontro Nacional de Geógrafos Urbana (XVII ENG). Belo Horizonte, 2012.

Artigo encaminhado para publicação em outubro de 2012.

Artigo aceito para publicação em outubro de 2012. 